\title{
OIL HYDROCARBONS IN SHELF WATERS OF THE EASTERN PART OF THE SAKHALIN ISLAND: THEIR INPUTS, TRANSFORMATIONS AND CONTENTS
}

\author{
Leonov A.V. ${ }^{1}$, Pishchal'nik V.M. ${ }^{2}$, Petukhov V.I. ${ }^{3}$, Chicherina O.V. ${ }^{1}$ \\ ${ }^{1}$ Shirshov Institute of Oceanology, Rusian Academy of Sciences \\ 36, Nahimovskiy prospekt, Moscow, 117997, Russia \\ ${ }^{2}$ Sakhalin State University, 290, Lenin Street, Uzhno-Sakhalinsk, 693008, Russia \\ ${ }^{3}$ Far Eastern Federation University, 8, Sukhanova St., Vladivostok, 690091, Russia \\ e-mail:leonov@ocean.ru \\ Submitted 16.02.2019, accepted 29.04.2019
}

\begin{abstract}
On the basis of the methodology of mathematical modeling, the development of the transformation of oil hydrocarbons in the waters of the eastern shelf of Sakhalin Island is considered. Three electronic instruments for the analysis of oceanographic information were used: 1. GIS "Sakhalin shelf" (for processing and systematization of thermohaline observed parameters); 2. The oceanic model of the Bergen University (for calculating the velocities and directions of currents, and also flow rates of water exchange between the individual regions on the Sakhalin Shelf); and 3. CNPSi-model (for calculating the biotransformation of oil hydrocarbons taking into account the intra-annual changes of the long-term marine environment parameters and features of the substance transfer at the water exchange). The entire eastern shelf of the Sakhalin Island was subdivided on two Water Areas (1. southeastern and 2. northeastern ones), where Regions 1-3 and 1-4 were respectively allocated. Using the methodology of mathematical modeling, the CNPSi-model reproduces the interactions of the changing environmental factors during a year (temperature, light intensity, water transparency, oil hydrocarbon inputs from external sources, conditions of the water regime) and their influence on the biotransformation of oil hydrocarbons in two-layer marine environment. The model calculates the changes during a year of the oil hydrocarbon concentrations, the biomass of $B 2$ bacteria (they oxidize of the oil hydrocarbons) and their activity indexes (the specific growth rate, the total biomass turnover time and the biomass production). An analysis is made of the changes in these parameters depending on environmental factors and conditions of substance transport during water exchange across the boundaries of regions and with open water areas of the Sea of Okhotsk. For each region studied, the characteristic values of these parameters were revealed for specific periods of a year. Calculations show that there are different conditions for the formation of $B 2$ bacteria biomass and their production on the south and north regions of the eastern shelf of the Sakhalin Island. In Regions 1-3 of the southeastern part of the shelf (Area 1), a significant effect of water dynamics was found on the development of the biomasses of organisms and, in particular, on the $B 2$ biomass.
\end{abstract}

Keywords: oil hydrocarbons, biomass of oil-oxidizing bacteria in the sea waters of the eastern shelf of the Sakhalin Island; inputs, biotransformation and dynamics during a year; bacteria activity indicators (specific growth rate, biomass turnover, production) 


\section{Introduction}

At this time, almost all the water areas of the Sakhalin shelf are directly or indirectly affected by anthropogenic impact: in some cases this is due to exploration, in others - to industrial development of deposits, pollution of the marine environment due to leakage of oil hydrocarbons (OHC) or their seepage from the bottom (Polteva et al., 2009), as well as with the growth in the volume of $\mathrm{OHC}$ transport. International experience in the development of offshore oil and gas fields has shown that the inevitable pollution of the marine environment with highly mineralized wastewater, crude oil, chemical reagents, hydrogen sulfide, biogenic substances (BS) is the consequence of anthropogenic activities in coastal waters and on the open marine areas. The pollution disrupts the accomplishment of natural ecological processes of BS transformations, the development and formation of phyto- and zooplankton biomasses (the forage base of the marine community). In general, the development of offshore oil and gas fields leads to a decrease in the biopotential of the marine environment and to its degradation (partial or irreversible) (Fashchuk et al., 2003). Therefore, in present modern practice, studies of the conditions of the state of organisms and their implementation of the biotransformation processes of BS and $\mathrm{OHC}$ in the marine environment are relevant. These studies create the scientific basis of knowledge about the natural potential of the marine environment in the process of its self-purification, and they are especially important when the marine environment is not yet disturbed and retains its natural functions in the transformation and "processing" of the organic and mineral substrates of natural origin that exist in it, as well as a number of pollutants, in various ways falling into the marine environment.

One of the topical studies of this problem is related to system investigations based on mathematical modeling. This paper presents the results of a similar study for the southeastern and northeastern sections of the Sakhalin Shelf (the district of industrial development of shelf hydrocarbon deposits).

The study was carried out with the help of the hydroecological CNPSi model (Leonov, 2012), which is intended to study the interrelated biogeochemical cycles of $\mathrm{N}$ - and $\mathrm{P}$ substances, it includes a simplified description of $\mathrm{Si}$ and dissolved organic $\mathrm{C}$ (DOC) transformation fluxes, changes in dissolved $\mathrm{O}_{2}$ and $\mathrm{OHC}$ in a two-layered marine system. The model reproduces the development of biotransformation processes of BS and organic matter $(\mathrm{OM})$ by a community of organisms including heterotrophic bacteria $(B 1)$, OHC-oxidizing bacteria (B2), three dominant phytoplankton groups $(F 1, F 2, F 3)$ and two zooplankton groups - herbivorous $(Z 1)$ and predatory $(Z 2)$. With the help of CNPSimodel, it is possible to study the effect on the marine ecosystem of the main natural and anthropogenic factors that serve as inputs data, correcting the rates in the concentration changing of the main chemical and biological parameters defining the state of the marine environment in different areas of the studied water body. Therefore, it is recommended to apply the model both in solving various water and ecological problems and in studying the features of the water ecosystem behavior under natural regimes of their functioning, and also in assessing their state with pronounced anthropogenic impact on individual regions 
of the water body. In this case, the analysis of simulation data obtained for different marine regions allows one to identify the differences and peculiarities of the biotransformation conditions and the cycling of chemical variables, along with the specific features of the formation and of changes in the bioproduction of the marine environment for specified external (natural and anthropogenic) impacts on the marine ecosystem.

The CNPSi model calculates the intra-annual dynamics of concentrations of chemical variables and biomass of the community's organisms (including $\mathrm{OHC}$ and $\mathrm{OHC}$ oxidizing bacteria $B 2$ ). Biotransformation of $\mathrm{BS}, \mathrm{OM}$ and $\mathrm{OHC}$ in the CNPSi-model is formalized on the basis of existing concepts of the substance turnover in the aquatic environment with simultaneous consumption of certain substrates by corresponding organisms, release of metabolic products to the external environment, and the dying of biomass (detritus formation). Heterotrophic bacteria $B 1$ consume organic compounds and detritus and in the process of metabolism form and maintain a mineral reserve of BS in water. OHC-oxidizing bacteria $B 2$ consume the $\mathrm{OHC}$ content available in the water environment. The dominant groups of phytoplankton are diatoms $(F 1)$, and other groups (F2 and F3) (Zakharkov et al., 2007; Mogil'nikova et al., 2003) consume the mineral BS for the formation of their biomass, and with their lack - and some fraction of organic fractions of biogenic elements. The functional role of zooplankton is reduced to the regulation of the development of other organism biomasses (or the rate of growth of their biomass), which on the whole indirectly affects the biotransformation of BS and OM in the aquatic environment. The development of all groups of organisms is accompanied by the consumption of $\mathrm{O}_{2}$, the formation of a corresponding stock of metabolites and detritus (dead biomass), used as substrates-feeding by other organisms. The stock of detritus, formed by organisms, is partially deposited in the lower layers and partially transformed to dissolved organic fractions, compensating for their losses (at the destruction processes) and maintaining their stock in the aquatic environment.

Biomass of bacteria $B 1$ is calculated in units of $\mathrm{C}, \mathrm{N}, \mathrm{P}$, and $\mathrm{Si}$, of bacteria $B 2$ - in units of consumed $\mathrm{OHC}$, of phytoplankton $F 1$ - in units of $\mathrm{Si}, \mathrm{N}$, and $\mathrm{P}$; of other phytoplankyon groups, $F 2$ and $F 3$, - in units of $\mathrm{N}$ and $\mathrm{P}$; of herbivorous zooplankton, $\mathrm{Z1}$ - in units of Si, N, and P; and of predatory zooplankton, Z2 - in units of $\mathrm{N}$ and $\mathrm{P}$.

The input data for playing the CNPSi-model includes the monthly average values of external factors (temperature, light intensity, transparency of the water, nutrient loading, water exchange parameters) that reproduce the development of the transitional states of the studied ecosystem, traced by the intra-annual change in the concentrations of chemicals substances and organism biomasses. Thus, the model allows studying the reaction of the aquatic ecosystem to the changing external and internal factors determining the state of the marine environment. As a result of their impact, a continuous transition to new states of the marine environment is formed, and in each selected region of the studied ecosystem (up to 10 regions can be studied simultaneously). These changing states of the marine environment can differ substantially. To analyze the changes taking place in the ecosystem, a wide range of calculation parameters (concentration of substances, the speed of individual processes, internal flows of substances in all transformation ways 
considered in the model, biogenic load, productivity of individual links of the trophic chain, etc.) are used.

The structure of the CNPSi-model equations is considered in detail in (Leonov, 2012). The program of the model is written in REM-FORTRAN. Visualization of modeling results was carried out on the basis of an improved system for displaying calculated data, adapted for WINDOWS-XP (Leonov et al., 2012).

\section{Zoning of the Eastern Shelf of Sakhalin}

According to the analysis of the oceanological parameters of the marine environment state, Areas 1 and 2 are considered within of the Eastern Shelf of Sakhalin Island (Fig. 1).
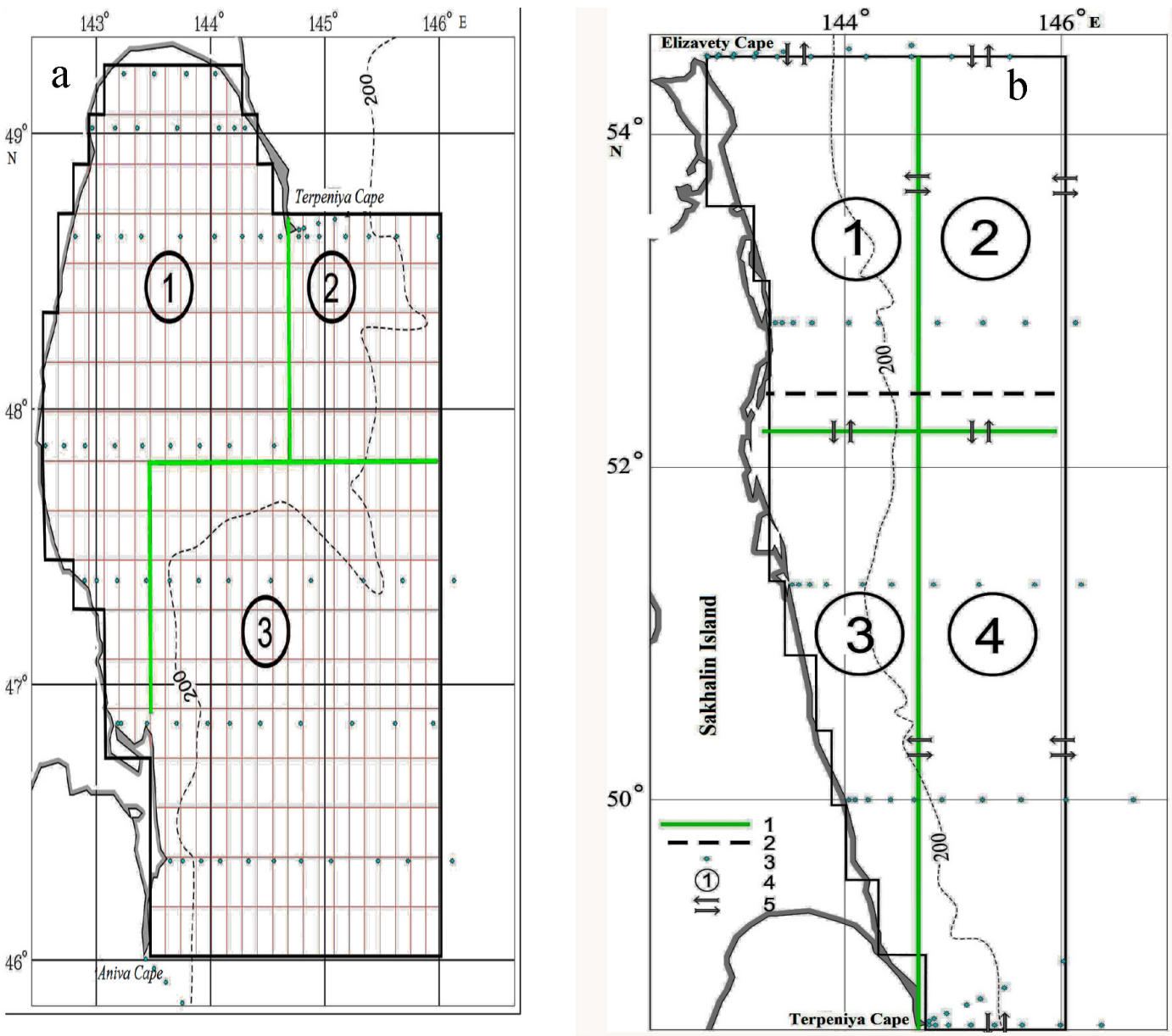

Fig. 1. Subdivisions of Areas 1 and 2 of Eastern Shelf of Sakhalin Isl. on Regions 1-3 and 1-4 respectively: 1 - boundaries between regions; 2 - the standard cross-section for Area 2; 3 - the location of standard stations in regions; 4 - number of regions; 5 - directions of water transfer though boundaries.

In Area 1, the Regions 1-3 are allocated: Region 1 - the Terpeniya Bay and adjacent shallow water areas; its average depth is $61 \mathrm{~m}$; Regions 2 (transit of waters along the continental slope) and 3 (western periphery of the Kurile Basin) have average depths of 677 and $2048 \mathrm{~m}$, respectively. The smallest area is for the Region 2 (10.8 thousand $\mathrm{km}^{2}$ ), 
and for Regions 1 and 3, they are 28.0 and 36.0 thousand $\mathrm{km}^{2}$, respectively. The volumes of water contained in Regions 1-3 are respectively 1.71, 7.31 and 73.73 thousand $\mathrm{km}^{3}$. The basis for oceanographic analysis of waters in Area 1 was the results of observations at 6.6 thousand deep-water stations (of which 4.3 thousand were performed on standard sections (Pischal'nik, Bobkov, 2000)). The features of the hydrochemical regime of waters are described in the fundamental study "The Project of the Sea" (Luchin et al., 1993; 1998) and in (Luchin, 2007).

In Area 2, Regions 1-4 are identified: Regions 1 and 2 are located to the north of $52^{\circ} 15^{\prime} \mathrm{N}$ up to $54^{\circ} 25^{\prime} \mathrm{N}$ (the latitude of cape Elizabeth); the boundary between Regions 1 and 2 passes along the meridian $144^{\circ} 43^{\prime}$ E., and the eastern boundary of Region 2 along the meridian of $146^{\circ} 00^{\prime} \mathrm{E}$; Regions 3 and 4 are located north of $48^{\circ} 38^{\prime} \mathrm{N}$. (latitude cape Terpeniya) to $52^{\circ} 15^{\prime} \mathrm{N}$; the eastern boundary of region 3 passes along the meridian $144^{\circ} 43^{\prime} \mathrm{E}$, and Region 4 - along the meridian $146^{\circ} 00^{\prime} \mathrm{E}$. The average depths of Regions $1-4$ are $640,1520,300$ and $730 \mathrm{~m}$, respectively. The smallest values of the surface area and volume of water are respectively in the Regions 2 (15 thousand $\mathrm{km}^{2}$ ) and 3 (10.5 thousand $\mathrm{km}^{3}$ ). The maximum values of the surface area and water volume are characterized by Region $1-48$ thousand $\mathrm{km}^{2}$ and 30.7 thousand $\mathrm{km}^{3}$ respectively.

Oceanographic analysis of sea water indicators in Area 2, based on data from deepsea observations at $\sim 1.3$ thousand stations, allowed the restoration of hydrological and hydrochemical data during the winter period and significantly clarified certain ideas about the water regime (Luchin, 1987; 2007; Luchin, Zhigalov, 2006).

According to the given average values of $\mathrm{OHC}$ concentrations and flow rates of triburaries, the monthly $\mathrm{OHC}$ inputs into the surface layer of Terpeniya Bay (Area 1) was estimated. At the same time, one can note the following peculiarities: $\sim 70-85 \%$ of the annual $\mathrm{OHC}$ input from river runoff into the waters of Region 1 occurs in May-June; in winter it is the smallest $(<5 \%)$; and for the summer and autumn months, a total of $\sim 10-25 \%$ of the annual $\mathrm{OHC}$ inpur (distributed over the months almost uniformly). In a year, 1.6 thousand tons of $\mathrm{OHC}$ enter to waters of region 1 (Area 1).

In addition to river flow, potential sources of $\mathrm{OHC}$ for the waters of Area 1 are: natural processes of $\mathrm{OHC}$ release from the bottom and transfer of $\mathrm{OHC}$ from the northern regions of the Sakhalin Shelf, where active work is being done to extract hydrocarbon raw materials. According to the sources mentioned, there is practically no information in the literature, therefore for them expert estimates were used in the calculations.

For Area 2, there are several OHC sources: in the upper layer - the runoff of the river Tym' (for Region 3), the water exchange with open waters of the Sea of Okhotsk (for Regions 2 and 4) and with neighboring areas (for Regions 1, 2, 4); in the lower layer - in Regions 1-4, the OHC is supplied by water exchange and additionally - with the natural OHC release from the bottom (Polteva et al., 2009). Potential pollution of sea waters as a result of active work on $\mathrm{OHC}$ production and emergency situations with the OHC spills are also possible (Patin, 2008). However, in the literature there is practically no quantitative information on the $\mathrm{OHC}$ supply to the marine environment from different sources to the waters of Area 2. An example of indirect estimating the $\mathrm{OHC}$ input (or 
OHC load) for nine regions of the White Sea when calculating the dynamics of OHC concentrations in the marine environment is presented in (Leonov et al., 2017).

Taking into account the average long-term monthly flow rates of river Tym', the estimated annual $\mathrm{OHC}$ input with river runoff into the surface layer of sea water for in Region 3 is 50 tons of OHC (61.9\% in May-June, 31.9\% in July-November, and $6.2 \%$ in December-April). The annual runoff of the $\mathrm{OHC}$ with waters of the river Tym' in 50 tons of $\mathrm{OHC}$ is quite acceptable, considering the generally small annual runoff of this river and the available quantitative benchmark: the estimated annual flow of OHC to the southwestern part of the sea with a river runoff of 75-85 tons (Lebedeva, 2001).

The range of changes in the $\mathrm{OHC}$ amount coming from water exchange to the upper layer in different months through the boundaries between Regions 1, 2 and 4 are respectively $0.11-12.22,0.00-11.30$ and $0.00-27.87$ thous. $t$ of $\mathrm{OHC} / \mathrm{month}$. In the course of water exchange between the regions, the "net" flow of OHC (taking into account the losses for return removal by water flow) to Regions 1, 2 and 4 was respectively 29.40, 38.28 and 63.48 thous. $t$ of $\mathrm{OHC} / y e a r$ (in Region 3 this flow is negative $(-131.20$ thous. $t$ of $\mathrm{OHC} / y e a r$, since the $\mathrm{OHC}$ removal is significantly higher in comparison with its input). When water was exchanged with the open waters of the Sea of Okhotsk, the "net" OHC flow to regions 2 and 4 was 25.09 and 42.50 thous. t, respectively, and for the Region 1 this flow is negative ( -49.44 thous. $t$ of $\mathrm{OHC} /$ year), and for Region 3 there is no water exchange with the open waters of the Sea of Okhotsk.

Taking into account the calculated $\mathrm{OHC}$ concentrations, at each step the vertical transport of the OHC between the upper and lower layers is estimated. With vertical transfer, the differences in the concentrations of substances (including $\mathrm{OHC}$ ) in the upper and lower layers are smoothed, since the direction of transport is determined by the concentrations of $\mathrm{OHC}$ (from higher concentrations to lower ones).

The rates of $\mathrm{OHC}$ release from the bottom were estimated taking into account the available information on the receipt of the $\mathrm{OHC}$ from this source into the World Ocean (estimated at 0.6 million $\mathrm{t}$ / year, or $46 \%$ of the total $\mathrm{OHC}$ input -1.3 million $\mathrm{t}$ / year from all sources) (Nemirovskaya, 2013a). With a high gas content of bottom sediments, the $\mathrm{OHC}$ release from the bottom can provide at least $50 \%$ of the total $\mathrm{OHC}$ input in the shelf waters of Russia (Nemirovskaya, 2013b). Obviously, this can be with the significant role of other $\mathrm{OHC}$ sources, and in their absence, the role of $\mathrm{OHC}$ release from the bottom can be much higher than $50 \%$. In this study, the available information on the $\mathrm{OHC}$ concentrations in the marine waters of Area 2 (Nemirovskaya, 2013a) was taken into account, and the $\mathrm{OHC}$ release from the bottom was estimated using numerical experiments: in a series of preliminary calculations, the rates of $\mathrm{OHC}$ release from the bottom were estimated, the lower layer (on the average in the water areas of the regions) during the year the OHC concentrations did not exceed the values of maximum permissible content (MPC) established by observations (Nemirovskaya, 2013a).

Thus, in Regions 1-4 (Area 2), the accepted expert estimates of the rates of OHS release from the bottom, varying throughout a year were respectively within $(0.343-2.948) \times 10^{-3},(0.1-3.769) \times 10^{-3},(0.1-2.4) \times 10^{-3}$ and $(0.277-3.769) \times 10^{-3} \mathrm{mg} \mathrm{OHC} /$ (L $\times$ day). At such rates of $\mathrm{OHC}$ release from the bottom in different months, acceptable 
OHC concentrations in the lower layer (all < MAC) were obtained with changes twice in a year of the directions of vertical transport (here, conventionally, the vertical transfer from the upper layer to the lower one is called «negative», and the reverse transfer from the lower layer in the top layer - as «positive»):

- in Regions 1 and 2 - the negative vertical transfer of OHC occurs from February to June, in the remaining months - the transfer is positive;

- in Region 3 - the negative vertical transfer of $\mathrm{OHC}$ is effective from December to July, and positive transfer is from August to November;

- in Region 4 - the negative vertical OHC transfer is effective from February to July, in the remaining months of a year (August-December), the transfer is positive;

- the values of the $\mathrm{OHC}$ transferred vertically are estimated for each month, and the calculated values of the vertical OHC transfer for a year give an idea of the vertical dominant $\mathrm{OHC}$ transfer in the region over the course of a year.

In Area 2, in comparison with remote from the coast Regions 2 and 4, the coastal Regions 1 and 3 are in the area of active development of OHC deposits and, therefore, potentially surface water of Regions 1 and 3 are susceptible to pollution (due to possible losses of $\mathrm{OHC}$ during work on their production and intensive marine $\mathrm{OHC}$ transportation). It is known that when drilling wells and exploiting oil layers in the sea, the formation and sewage with a hydrocarbon content of up to $15 \mathrm{mg} / \mathrm{L}$ are discarded (Patin, 2008). This means that even in accident-free mode, the pollution of the marine environment is possible. For example, the estimated annual $\mathrm{OHC}$ flow is 2.1 tonnes to the PiltunAstokhskoye field, located in 11 miles from the coast and where the work is being done (Lebedeva, 2001).

The annual $\mathrm{OHC}$ input to the World Ocean during $\mathrm{OHC}$ transport is estimated at 600 thous. $t$ (Nemirovskaya, 2013a). A recalculation from this value per unit of water area showed that $148 \mathrm{t}$ of OHC can be supplied to the White Sea due to sea OHC transportation (Leonov et al., 2017), and this estimate "enters" in the range of 50-200 t of OHC, which for the navigation period can enter into the marine environment as a result of discharges of bilge water and during emergency spills during the operation of vessels along the Sevmorputi route (Lebedeva, 2001).

A comparison of environmental parameters values for Areas 1 and 2 showed that there are significant differences in these input data used for the calculations on CNPSi-model:

- the values of mean depths and water volumes in Regions 1-3 (Area 1) as well as between these parameters in Regions 1-3 (Area 1) and Regions 1-4 (Area 2);

- in $T_{\mathrm{w}}$ values: in regions of Area 1, in the upper layer they are generally higher than in regions of Area 2; in Regions 1-3 (Area 1) in the lower layer, values of $T_{\mathrm{w}}$ remain positive throughout a year, and in regions of Area 2 they are positive only in Regions 2 and 4 distant from the coast;

- in values of the vertical water exchange: it is generally higher in regions 1-3 (Area 1) in comparison with Regions 1-4 (Area 2);

- in values of horizontal water exchange: there are essential differences in their values between regions in Areas 1 and 2 . 
On the Eastern Shelf of Sakhalin Island, the reorganization of the water circulation in the surface 100-m layer occurs twice in the annual cycle: in May-June and SeptemberOctober. The calculated velocities of water movement under ice in the Areas 1 and 2 vary respectively from 10 to 12.5 and from 4 to $7 \mathrm{~cm} / \mathrm{sec}$. Maximum water velocities on the surface are observed in November: equal to $22.5 \mathrm{~cm} / \mathrm{sec}$ (Area 1) and $21.5 \mathrm{~cm} / \mathrm{sec}$ (Area 2) (Pishchal'nik et al., 2014; 2017).

Differences in the morphometric figures, the values of marine environment parameters, water exchanges (vertical - between layers and horizontal - between the regions and with the open waters of the Sea of Okhotsk) have an impact on the development biohydrochemical processes in the marine environment, as well as on the formation of the values of the generalized indexes of the marine environment - the value of bioproduction in different regions of Areas 1 and 2.

\section{The calculated dynamics of $\mathrm{OHC}$ concentrations, the biomass of $\mathrm{OHC}-\mathrm{oxidizing}$ bacteria $B 2$ and their activity in Areas 1st and 2nd of the Eastern Shelf of Sakhalin Island}

Calculations on CNPSi model (Leonov, 2012) was carried out for a bilayer system with a time step of 0.05 day by the Runge-Kutta 4 method for the calendar year (1 January - 31 December). The next input data were used in calculations for regions in Areas 1 and 2: morphometric parameters of regions (mean depths, areas and volumes of water), mean monthly values of $T_{w}$, light intensity, water transparency, water regime characteristics (water flow rates for water exchanges between regions and with open sea areas of the Sea of Okhotsk, parameters of substance load onto the marine environment). The CNPSi-model was run for a two-year period to determine the initial concentrations of $\mathrm{BS}, \mathrm{OM}$ and $\mathrm{OHC}$ for the second year that meet the specified long-term mean values of input parameters. This is the so-called condition of "circuit of the year" (or conforming to the values of concentrations at the beginning and at the end of the second year). Similar concentrations of substances at the beginning and end of a year serve as a reliable criterion of balance between developing in the aquatic environment processes - their inputs during a year, development biohydrochemical processes in the water environment and the influence of environmental factors, determining the reference state of the ecosystem, the development of transient processes (or response of ecosystems to changes during a year) and return to its natural state at the end of a year, at the conclusion of external influences on the ecosystem.

Next, the text in this section discusses the calculated concentrations of $\mathrm{OHC}$, the biomass of the $\mathrm{OHC}$-oxidizing bacteria $B 2$ and their activity parameters $-k_{0 B 2}$ (the specific growth rate of bacteria $B 2$, day ${ }^{-1}$ ) and $\operatorname{tr}_{B 2}$ (the turnover time of biomass $B 2$, day) in the waters of the regions identified in Area 1 (for the upper layer) and Area 2 (for the upper and lower layers) on the Eastern Shelf of Sakhalin Island.

In the waters of Regions 1-3 (Area 1) since the beginning of a year, the $\mathrm{OHC}$ concentrations vary in different ways. In Region 1, there were two periods in changes of the OHC concentrations: their small variations were noted up to 109th days, followed 
by an increase of concentrations at a rate of $7.487 \times 10^{-4} \mathrm{mg} \mathrm{OHC} /(\mathrm{L} \times$ day $)$ up to 137 th days. In Regions 2 and 3, the increase in OHC concentrations occurs from the beginning of a year to 39th and 41st days, respectively, at rates of $2.472 \times 10^{-4}$ and $6.841 \times 10^{-4} \mathrm{mg}$ $\mathrm{OHC} /(\mathrm{L} \times$ day) (Fig. 2a). After the winter maximum, the $\mathrm{OHC}$ content is reduced to the minimal values (conditionally background) with differences in each region and by values, and by the time frame for achieving: respectively, in Regions 1-3 of the 159th, 173rd and 152 nd days $(0.002,0.0002$ and $0.0008 \mathrm{mg} \mathrm{OHC/L})$. In Region 1, a small maximum $(0.006 \mathrm{mg} \mathrm{OHC} / \mathrm{L})$ is formed in the summer period (at $233 \mathrm{rd}$ day) which already falls to the background values $(0.002 \mathrm{mg} \mathrm{OHC} / \mathrm{L})$ by the 150 ty day; from 308 th day, the OHC content in Region 1 begins to increase. In Regions 2 and 3, the period of the minimum OHC content values continues to 322nd and 329th days respectively (Fig. 2a).
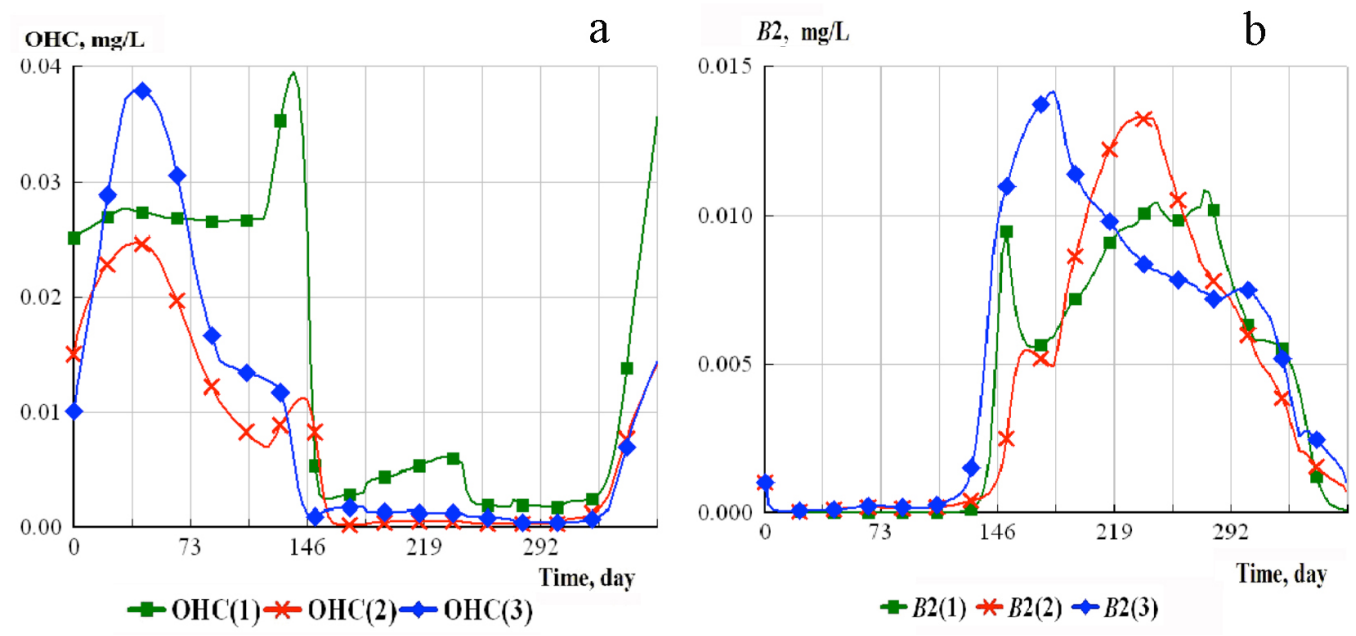

Fig. 2. Calculated dynamics of $\mathrm{OHC}$ (a) and biomass of OHC-oxidizing bacteria $B 2$ (b) in the Regions 1-3 (Area 1) (upper water layer)

In Regions 1-3 (Area 1) since the beginning of a year, the period of low biomass $B 2$ values (up to 132nd, 111st and 104th days) has been preserved. Its active development and subsequent changes in each region pass differently (Fig. 2b). In Region 1, two maxima of bacteria $B 2$ biomass form: a sharp peak at $152 \mathrm{nd}$ day $(0.0095 \mathrm{mg} \mathrm{OHC} / \mathrm{L}$ at the highest values of $k_{0 B 2}\left(0.238\right.$ day $^{-1}$ on the 137 th day) and a sufficiently long period of its increased values by 236-281st days (with biomass fluctuations in the range 0.0097-0.0106 $\mathrm{mg}$ $\mathrm{OHC} / \mathrm{L}$ at relatively low values of $k_{0 B 2} 0.011$ day $^{-1}$ ) (Fig. 3a). In the Regions 2 and 3, the highest biomass $B 2$ values are reached at the 236th and 180th days $(0.013$ and $0.014 \mathrm{mg}$ $\mathrm{OHC} / \mathrm{L})$ (Fig. 2b), while the largest values of $k_{0 B 2}\left(0.103\right.$ and $\left.0.130 \mathrm{day}^{-1}\right)$ occur on the 154th and 135th days respectively (Fig. 3a).

Features of the intra-annual change of $B 2$ biomass values are illustrated by the indicator of their activity - the turnover time of $B 2$ biomass $\left(\operatorname{tr}_{B 2}\right)$ (Fig. 3b). In Region 1 until the middle of April, the mean value of $t r_{B 2}$ is 9.8 days (means a slow $B 2$ biomass turnover), and in Regions 2 and 3 - the activity of $B 2$ biomass is sharply increased (and the $\operatorname{tr}_{B 2}$ value are within 0.5-0.8 days). At the same time, the $B 2$ biomass remains low (Fig. $2 \mathrm{~b}$ ), and the intensification of its activity is a consequence of the intensive water exchange 
(water mass transfer and the corresponding influence on $\mathrm{OHC}$ concentrations and $B 2$ biomass values) across the boundaries of regions. In the second half of April, the activity of $B 2$ biomass increases (and its growth begins). In this case, the $t r_{B 2}$ value in the Region 1 is sharply reduced (the metabolism is accelerated), and from 130ty day to $\sim 317$ th days, the $t r_{B 2}$ value in Regions 1-3 vary synchronously: from May to mid November, the $t r_{B 2}$ values are very similar (2.0-2.2 days) (Fig. 3b).
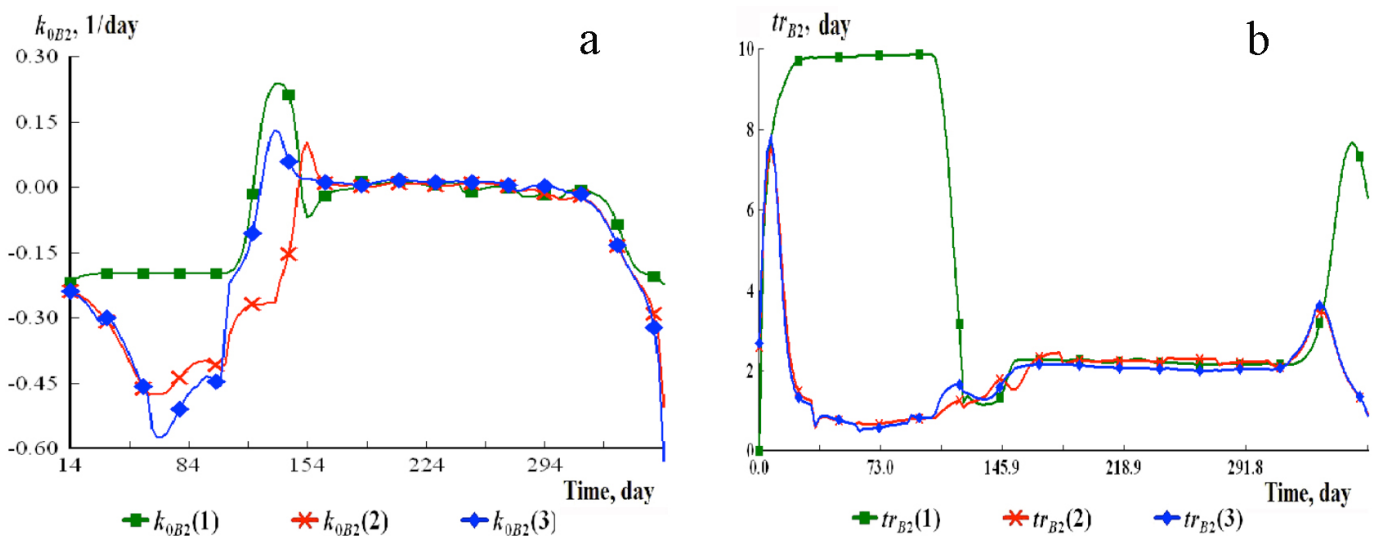

Fig. 3. Calculated annual dynamics of activity parameters of $B 2$ biomass: (a) $k_{0 B 2}$ and (b) $t r_{B 2}$ in waters of Regions 1-3 (Area 1) for the upper water layer.

In the period (156-294th days), the $B 2$ biomass in each region corresponds to the background $\mathrm{OHC}$ concentrations, the values of $k_{0 B 2}$ fluctuate near zero values and show, on the whole, the conditions close to equilibrium for which the $B 2$ biomass varies within its mean values. In November-December, the $B 2$ biomass activity decreases, its biomass also decreases, and metabolic processes slow down. The period of active reduction of the $B 2$ biomass occurs in the last decade of November (from 320ty day). In the Region 1 , the $t r_{B 2}$ value increase to 6.2-7.6 days by the end of a year. In Decemver in Regions 2 and 3, the condition for the $B 2$ biomass is determined, as at the beginning of a year (by the water exchange), so the $t r_{B 2}$ values in the waters of these regions decrease to 0.6-0.8 days by the end of a year (Fig. 3b). After 329th day, the OHC concentrations in Regions 1-3 are increased, and by the end of a year they returned close to the values they had in the beginning of a year (Fig. 2a).

For Area 2 (Regions 1-4), the calculation results for the upper and lower layers are further presented, since for each layer the influence of the considered sources of OHC input into the marine environment are significant.

Upper layer. In Regions 1-4 from the beginning of a year, the $\mathrm{OHC}$ concentrations vary in a small ranges. The increase in the $\mathrm{OHC}$ concentrations begins at $\sim 125$ th day, and in June and July an intermediate maximum are formed: in Regions 1 and $2(0.0135$ and $0.0142 \mathrm{mg} \mathrm{OHC/L}$ ) at 180ty and 164th days respectively, and in the Regions 3 and $4(0.0734$ and $0.0252 \mathrm{mg} \mathrm{OHC} / \mathrm{L})$ on the 154th and 168th days respectively. After these maxima, the $\mathrm{OHC}$ concentrations decrease with rates that in Regions 1 and 3 vary within the range $(0.429-1.156) \times 10^{-3} \mathrm{mg} \mathrm{OHC} /(\mathrm{L} \times$ day $)$, and in Regions 2 and 4 within $(2.082-$ 
4.328) $\times 10^{-4} \mathrm{mg} \mathrm{OHC/(L} \mathrm{x} \mathrm{day).} \mathrm{Low} \mathrm{OHC} \mathrm{concentrations} \mathrm{in} \mathrm{Regions} \mathrm{1-4} \mathrm{(respectively}$ $\left.\sim 2.0 \times 10^{-4}, \sim 1.0 \times 10^{-4}, \sim 2.7 \times 10^{-3}, \sim 1.2 \times 10^{-4} \mathrm{mg} \mathrm{OHC} / \mathrm{L}\right)$ account for $\sim 196-315$ th days. By the end of a year, the $\mathrm{OHC}$ concentrations increase in Regions 1-4, respectively, to $4.430 \times 10^{-3}, 1.134 \times 10^{-2}, 4.809 \times 10^{-2}, 8.387 \times 10^{-3} \mathrm{mg} \mathrm{OHC} / \mathrm{L}$ (Fig. 4a).

In the Regions $1-4$ (Area 2), the low $B 2$ bacteria biomasses $\left(<1 \times 10^{-4} \mathrm{mg} \mathrm{OHC} / \mathrm{L}\right)$ remain from beginning of a year until the end of May. Only in July the values of $B 2$ biomasses in waters of Area 2 begin to exceed $1 \times 10^{-3} \mathrm{mg} \mathrm{OHC} / \mathrm{L}$, and in the second half of a year the $B 2$ biomass values significantly differ in each region. Active growth of $B 2$ biomass passes almost simultaneously (from 185th day) in Regions 2-4, and in Region 1 - it is started from the 197th day. The maxima of $B 2$ biomass in the waters of Regions 1 and 2 are reached respectively on the 245th and 272nd days (0.02517 and $0.02452 \mathrm{mg}$ of $\mathrm{OHC} / \mathrm{L}$ ), and the increased $B 2$ biomasses remains practically until the beginning of November. By 310-317th days, there is a sharp decrease in the $B 2$ biomass values.

In Regions 3 and 4, the $B 2$ biomass maximums are marked respectively on the 192nd and 219th days (0.01715 and $0.01452 \mathrm{mg} \mathrm{OHC} / \mathrm{L})$. Then the $B 2$ biomass values are reduced: in the Region 3 to $\sim 202$ nd day and then fluctuates to $\sim 317$ th day within 0.0140 $0.0122 \mathrm{mg} \mathrm{OHC} / \mathrm{L}$, and by the end of a year it decreases. In Region 4, the $B 2$ biomass
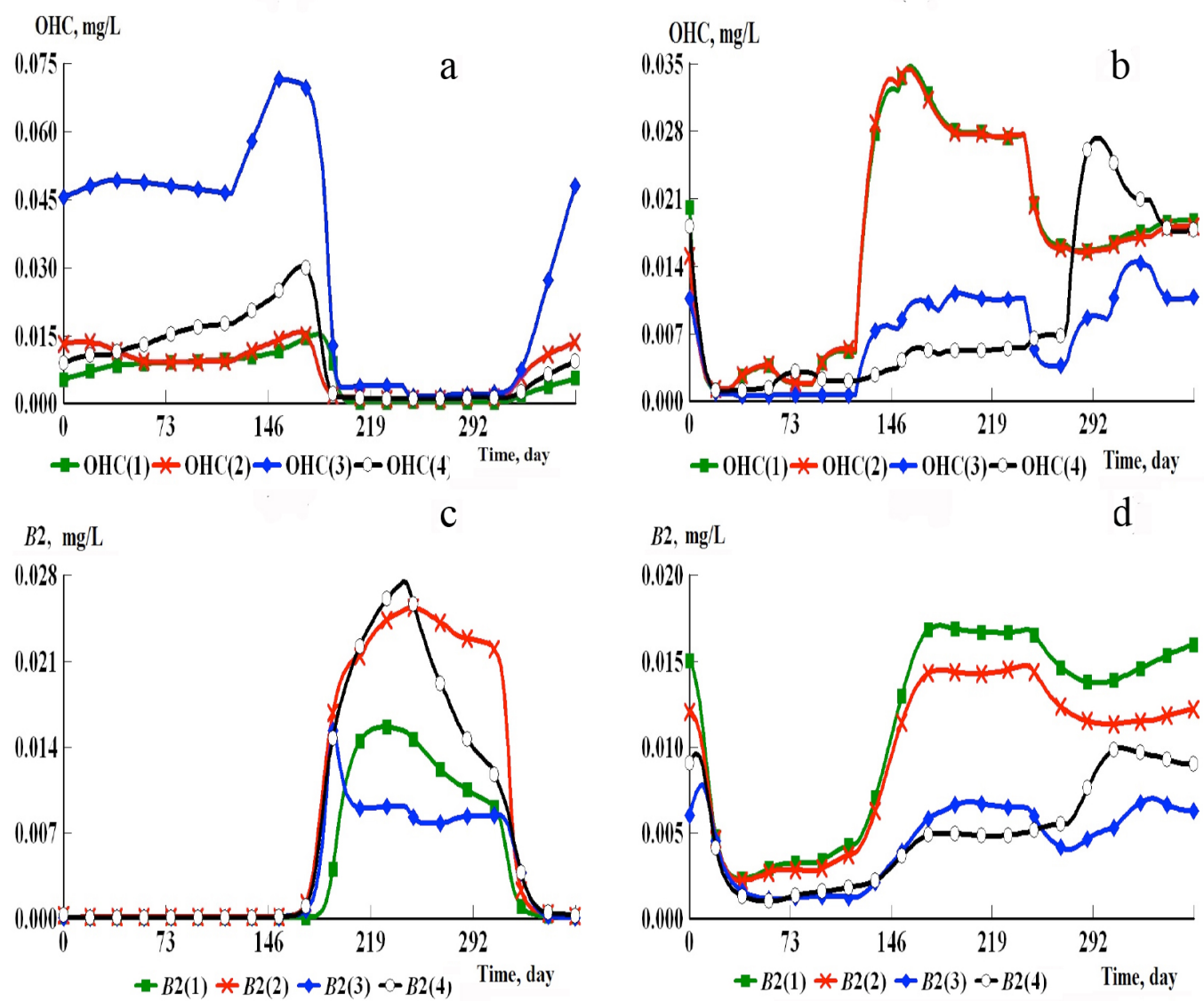

Fig. 4. Calculated annual dynamics of the OHC concentrations $(a, b)$ and biomass of OHC-oxidizing bacteria $B 2$ (c, d) in Regions 1-4 (Area 2); (a, c) - for the upper water layer, $(b, d)$ - for the lower water layer. 
decreases in two stages: on 243-315th days and further until the end of a year. In the last days of December, the $B 2$ biomasses in the waters of Regions 1-4 decrease accordingly to $(4.6-27.2) \times 10^{-5} \mathrm{mg} \mathrm{OHC} / \mathrm{L}$ (Fig. $4 \mathrm{c}$ ).

In Regions 1-4 (Area 2), the $B 2$ biomass maximum in the upper layer was formed at the highest values of $k_{0 B 2}\left(0.154-0.196\right.$ day $^{-1}$ with an active growth in the period of 171-188th days). When the greatest $B 2$ biomass values were reached (in Regions 1 and 3 on 226-281st days. And in Regions 2 and 4 on 220-305th days), the $k_{O B 2}$ values were changed within narrow limits (respectively $0.001-0.010$ and $0.010-0.020$ day $^{-1}$ ). From 312 nd day until the end of a year, the $k_{0 B 2}$ values in Regions 1-4 remained negative, and it was associated with a marked decrease of the $B 2$ biomass values in the waters of the upper layer (Fig. 5a).
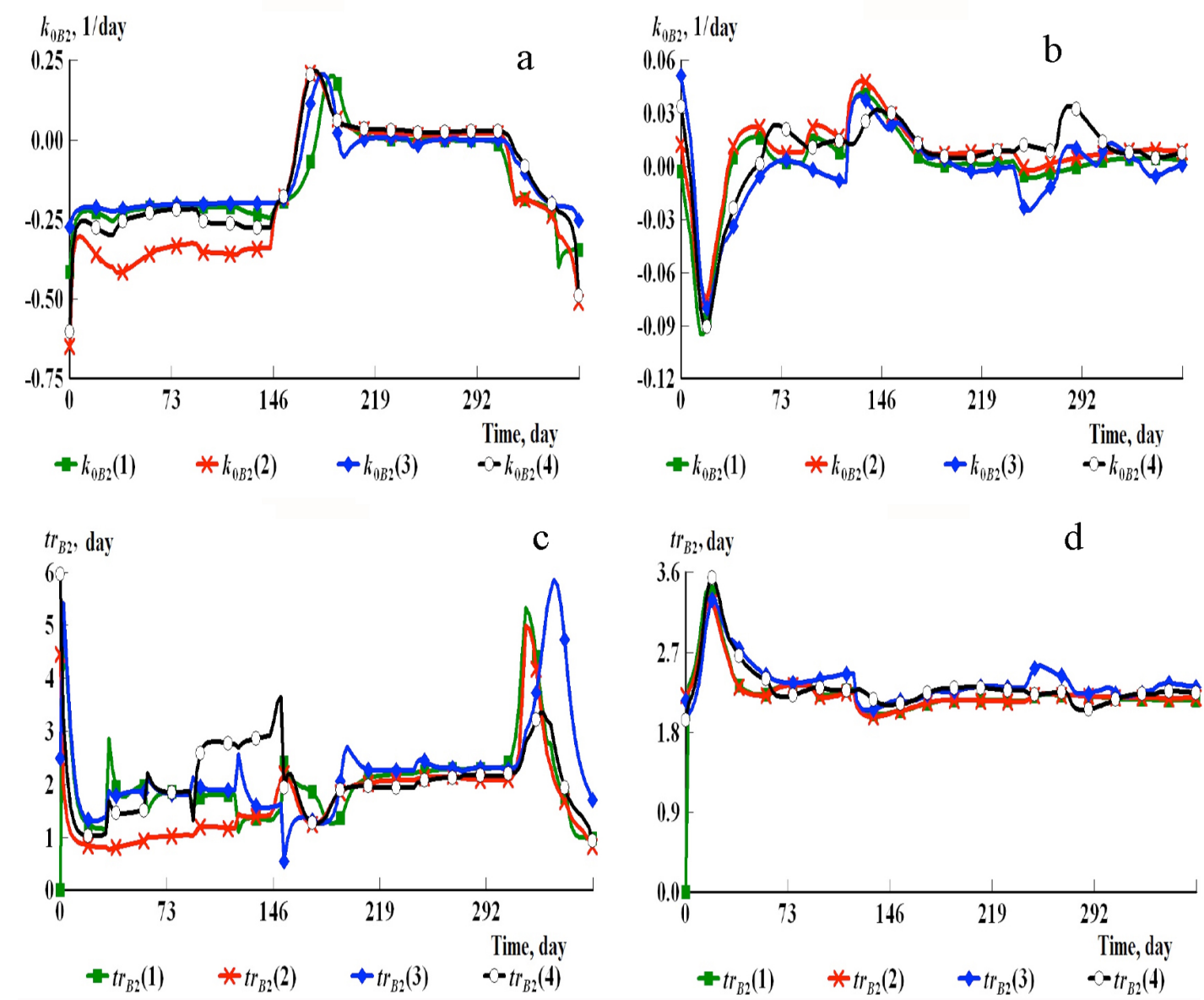

Fig. 5. Calculated annual dynamics of parameters showing the activity of $B 2$ biomass: $(a, b)-$ $k_{0 B 2}$ and (c, d) $-t r_{B 2}$ in waters of Regions 1-4 (Area 2); (a, c) - for $\backslash$ the upper water layer; and $(b, d)$ - for the lower water layer.

The complete turnover time of $B 2$ biomass $\left(\operatorname{tr}_{B 2}\right)$ before its active growth fluctuates in each region of Area 2 in the characteristic ranges: in the region 2 for $0.5-1.8$ days, and in other regions - slower (with amplitude of 1.0-3.0 days). In Regions 1-4, at the highest values of the $B 2$ biomass, the $t r_{B 2}$ values become close and equal to $\sim 2.0-2.2$ days during $\sim 224-305$ days. With a subsequent decrease in the $B 2$ biomass by the end of a year, the 
differences in the $t r_{B 2}$ values are found, while the trends of this parameter change remain in each region: first, the provess of the $B 2$ biomass turnover slows down (the $t r_{B 2}$ values increase to 3-6 days), and accelerates by the end of a year (the $t r_{B 2}$ values decrease up to 0.6-1.6 days) (Fig. 5c).

Lower layer. In comparison with the upper layer, in the lower layer the conditions of OHC transformation differ: positive values of $T_{\mathrm{w}}$ remain in it during a year, and there is a constant $\mathrm{OHC}$ input into the water environment from the bottom. Accordingly, the influence of these factors is reflected in the biotransformation of substances, and there are significant differences in the intra-annual dynamics of OHC concentrations, the ONSoxidizing bacteria $B 2$ biomass and their activity parameters $\left(k_{0 B 2}\right.$ and $\left.t r_{B 2}\right)$ (Fig. 4, 5).

Since the beginning of a year, in the lower layer the $\mathrm{OHC}$ concentrations have been rapidly decreasing (from the initial values $0.011-0.020 \mathrm{mg} \mathrm{OHC} / \mathrm{L}$ ) to an intermediate minimum: in Regions 1-2 at 80ty day (1.66-1.73) $\times 10^{-3} \mathrm{mg} \mathrm{OHC} / \mathrm{L}$, and in Regions 3-4 on the 27 th day $\left((0.71-1.01) \times 10^{-3} \mathrm{mg} \mathrm{OHC} / \mathrm{L}\right)$ (Fig. 4b). Further, the OHC concentrations in all regions change with a weak upward trend. From the 120ty day, the rates of increase in the $\mathrm{OHC}$ concentrations in Regions 1 and 2 increase to $(6.348-6.654) \times 10^{-4} \mathrm{mg} \mathrm{OHC} /$ (L×day), and by the 164th day they reach $(3.319-3.379) \times 10^{-2} \mathrm{mg} \mathrm{OHC} / \mathrm{L}$. In Regions 3 and 4, the rates of increase in the $\mathrm{OHC}$ concentrations during this period are lower (respectively $2.153 \times 10^{-4}$ and $5.928 \times 10^{-5} \mathrm{mg} \mathrm{OHC} /(\mathrm{L} \times$ day $)$ ) and accordingly lower their maxima for the 166 th day $\left(1.043 \times 10^{-2}\right.$ and $\left.5.456 \times 10^{-3} \mathrm{mg} \mathrm{OHC} / \mathrm{L}\right)$. The $\mathrm{OHC}$ concentrations in Regions 1-3 remain elevated to $\sim 243 \mathrm{rd}$ day, then they decrease, and on the 284th day in Regions 1 and 2, the OHC concentration values $\left((1.541-1.554) \times 10^{-2}\right.$ $\mathrm{mg} \mathrm{OHC} / \mathrm{L})$ were noted. In Region 3, this minimum falls on $293 \mathrm{rd}$ days $\left(8.436 \times 10^{-3} \mathrm{mg}\right.$ $\mathrm{OHC} / \mathrm{L}$ ). In Region 4, this minimum of $\mathrm{OHC}$ is not formed in this period (Fig. 4b).

In Regions 1-2 and 3-4 at the end of a year, the OHC concentrations vary in different ways. In Regions 1 and 2, after an intermediate minimum these concentrations increase with low rates, and by the end of a year their content reaches $(1.875-1.808) \times 10^{-2}$ $\mathrm{mg} \mathrm{OHC/L}$. In Region 3, the rate of increase in the OHC concentrations id higher after the intermediate minimum/ and it forms the second intermediate maximum $\left(1.435 \times 10^{-2} \mathrm{mg}\right.$ $\mathrm{OHC} / \mathrm{L}$ ) on the $322 \mathrm{nd}$ day, and by the end of a year, there is a decrease in OHC content to $1.077 \times 10^{-2} \mathrm{mg} \mathrm{OHC} / \mathrm{L}$. In region 4 , after a gradual increase in the $\mathrm{OHC}$ concentrations to 274 th day, a sharp increase followed with the formation of a maximum $\left(2.725 \times 10^{-2}\right.$ $\mathrm{mg} \mathrm{OHC/L}$ ) at the 296th day. Then in the Region 4, the content of OHC is reduced to $1.767 \times 10^{-2} \mathrm{mg} \mathrm{OHC} / \mathrm{L}$ by the end of a year (Fig. $4 \mathrm{~b}$ ).

In the lower layer in regions of Area 2 during the cold period (beginning and end of a year), the values of $B 2$ biomass remain high: at the beginning of the year in Regions 1 and 2 they are 0.015 and $0.012 \mathrm{mg} \mathrm{OHC/L}$, respectively, and in Regions 3 and $4-0.006$ and $0.009 \mathrm{mg} \mathrm{OHC} / \mathrm{L}$. During a year, they change depending on the environmental factors, and at the end of a year, in water environment their original their values are restored. Because of the increased values of $B 2$ biomass at the beginning of a year, the initial OHC content decreases in the lower layer in the first two months (Fig. $4 \mathrm{~b}$ ), and the $B 2$ biomass decreases in this layer (in Regions 1 and 2, respectively, to $7.04 \times 10^{-3}$ and $6.64 \times 10^{-3} \mathrm{mg}$ 
$\mathrm{OHC} / \mathrm{L}$, and in Regions 3 and $4-$ up to $2.10 \times 10^{-3}$ and $1.77 \times 10^{-3} \mathrm{mg} \mathrm{OHC} / \mathrm{L}$ ) (Fig. 4d). The growth of $B 2$ biomass begins with the end of spring at the increased $\mathrm{OHC}$ concentrations in waters of the lower layer. As a result by the 178th day, the the $B 2$ biomass are quite high in the lower layer: 0.0160-0.0169 and 0.0140-0.0147 mg OHC/L in Regions 1 and 2, respectively, and in a range 0.005-0.007 mg OHC/L in Regions 3 and 4 (Fig. 4d).

Similar values of $B 2$ biomass in Regions 1-4 are actually maintained until the middle of September (or until 254th day). Their subsequent changes are determined by the dynamics of the $\mathrm{OHC}$ concentrations at the end of a year: in Regions 1 and 2, after a small decrease in $B 2$ biomass, by the end of a year they increase (correspondingly to 0.0161 and $0.0122 \mathrm{mg} \mathrm{OHC/L}$ ), and in Regions 3 and 4, the $B 2$ biomass decreases respectively to 0.0062 and $0.0090 \mathrm{mg} \mathrm{OHC/L}$ ) (Fig. 4d).

The formation of the $B 2$ biomass maximum in the lower layer occurred at $k_{0 B 2}$ values, which differed between regions in terms of time, but not in values. Let's compare the values of $k_{0 B 2}$ : in Region 1 - by $128-142$ nd days $\left(k_{0 B 2}\right.$ is $0.035-0.038$ day $\left.^{-1}\right)$, in Region 2 - on $123-$ 149th days $\left(0.032-0.045\right.$ day $\left.^{-1}\right)$, in Region 3 - on the 125-140th days $\left(0.032-0.040\right.$ day $\left.^{-1}\right)$ and in Region $4-$ on the 135-161 st days $\left(0.025-0.032\right.$ day $\left.^{-1}\right)$. In the lower layer during the period of the highest values of $B 2$ biomass (178-254 days) the total range of the $k_{0 B 2}$ values was $0.001-0.010 \mathrm{day}^{-1}$. However for each region within this general range, it is possible to single out specific fluctuation ranges of the $k_{O B 2}$ values: $0.001-0.002,0.005-0.010,0.001-$ 0.009 , and $0.004-0.010$ day $^{-1}$ for Regions 1-4 respectively (Fig. 5b). Further and before the end of a year, the $k_{0 B 2}$ values in the lower layer vary in specific ranges, reflecting the dynamics of $B 2$ biomass in each region. In Regions 1 and 2, they change synchronously within $0.002-0.008 \mathrm{day}^{-1}$, in Region 3 - from -0.010 to $0.012 \mathrm{day}^{-1}$, in the Region $4-$ in the range of $0.010-0.034 \mathrm{day}^{-1}$. The final values of $k_{0 B 2}$ in the lower layer in Regions $1-4$ were $0.003,0.008,0.001$ and 0.007 day $^{-1}$, respectively (Fig. 5b).

The values of $\operatorname{tr}_{B 2}$ (the complete $B 2$ biomass turnover) in the lower layer (Fig. 5d) show that during a year, the conditions for the formation of $B 2$ biomass remain fairly stable and differ little between regions. Only at the beginning of a year, there are some differences in the formation of $B 2$ biomass: for the 16-24st days, the $\operatorname{tr}_{B 2}$ values in Regions 1-2 and 3-4 fluctuate within 2.4-2.5 and 3.0-3.5 days, respectively, to 34-44th days, these differences between regions are smoothed out, and in Regions 1-4 the the range of the $\operatorname{tr}_{B 2}$ values composed 2.5-2.8 day. In the rest of the time, the conditions for the formation of $B 2$ biomass in Regions 1-4 remain practically identical, and fluctuations in the $t r_{B 2}$ values were in the narrow range of 2.0-2.3 day (Fig. 5d).

\section{Features of changes in the production of $\mathrm{OHC}$-oxidizing $B 2$ bacteria in Areas 1 and 2 of the Eastern Shelf of Sakhalin Island}

The development of biomasses of organisms and biotransformation of BS and $\mathrm{OHC}$ in regions of Areas 1 and 2 are characterized not only by values of organism biomasses, specific rates of their growth $\left(k_{0 \mathrm{i}}\right)$ and biomass turnover times $\left(\operatorname{tr}_{B \mathrm{i}}\right)$, but also calculated values of organism bioproduction $\left(\mathrm{BP}_{\mathrm{i}}\right)$ which is represented by two different dimensions: 
1. Per unit of water volume, in $g$ of Element $/\left(\mathrm{m}^{3} \times\right.$ month $)$, and it allows to make the comparing $\mathrm{BP}_{\mathrm{i}}$ values (under different environmental conditions, in different regions and at different time periods) and also

2. For the entire volume of the considered water layer (in thous. $t$ of Element per month or per year) - reflects the dependence of $\mathrm{BP}_{\mathrm{i}}$ on the total mass of matter in the this layer.

Calculated values of $\mathrm{BP}_{B 2}$ biomass productions in regions of Areas 1 and 2 are presented in Tables 1 and 2 respectively.

For Regions 1 and 3 (Area 1), the values of $\mathrm{BP}_{B 2}$ for the May conditions are $4.096 \times 10^{-4}$ and $1.056 \times 10^{-3} \mathrm{~g}$ of $\mathrm{OHC} /\left(\mathrm{m}^{3} \times\right.$ month) (or 0.230 and 0.760 thous. $\mathrm{t}$ of $\mathrm{OHC} /$ month), respectively, and for Region 2 , the highest $\mathrm{BP}_{B 2}$ values are typical for July $4.382 \times 10^{-4} \mathrm{~g}$ of $\mathrm{OHC} /\left(\mathrm{m}^{3} \times\right.$ month) (or 0.142 thous. $\mathrm{t}$ of $\left.\mathrm{OHC} / \mathrm{month}\right)$. Autumn maximum of $\mathrm{BP}_{B 2}$ is only noted for Region 2: its value is $3.963 \times 10^{-4} \mathrm{~g}$ of $\mathrm{OHC} /\left(\mathrm{m}^{3} \times\right.$ month $)$ (or 1.070 thous. $t$ of $\mathrm{OHC} /$ month) (Table 1).

For Area 2, the production period for bacteria $B 2$ in the upper layer in Regions 1, 2 and 4 continues from June to November, and in Region 3 - from June to December (Table $2)$. The production values of the bacteria $B 2\left(\mathrm{BP}_{B 2}\right)$ on the water volume of the upper layer in individual months in Regions 1 and 2 vary within $0.001-0.727$ and $0.078-0.750 \mathrm{~g}$ $\mathrm{OHC} /\left(\mathrm{m}^{3} \times\right.$ month $)$, somewhat lower in Regions 3 and 4 (0.002-0.436 and 0.049-0.428 g $\mathrm{OHC} /\left(\mathrm{m}^{3} \times\right.$ month $)$, respectively). The maximum $\mathrm{BP}_{B 2}$ in Regions $1-4$ falls on September, October, July and August, respectively.

Table 1. Estimated positive values of $\mathrm{BP}_{B 2}$ for $\mathrm{OHC}$-oxidizing $B 2$ bacteria in regions 1-3 (Area 1)

\begin{tabular}{|c|c|c|}
\hline \multirow{2}{*}{ Month } & \multicolumn{2}{|c|}{ Production values of $\mathrm{OHC}$-oxidizing $\mathrm{B} 2$ bacteria } \\
\hline & $\mathrm{g}$ of $\mathrm{OHC} /\left(\mathrm{m}^{3} \times\right.$ month $)$ & $10^{3} \times \mathrm{t}$ of $\mathrm{OHC} /$ month \\
\hline \multicolumn{3}{|c|}{ Region I } \\
\hline May & $4.096 \times 10^{-4}$ & 0.2297 \\
\hline \multicolumn{3}{|c|}{ Region 2} \\
\hline July & $4.382 \times 10^{-4}$ & 0.1420 \\
\hline \multicolumn{3}{|c|}{ Region 3} \\
\hline May & $1.056 \times 10^{-3}$ & 0.7603 \\
\hline November & $3.963 \times 10^{-4}$ & 1.0700 \\
\hline
\end{tabular}

With the dimension of the $\mathrm{BP}_{B 2}$ for the entire volume of water, their values directly depend on the water volume of each layer and on the total $\mathrm{OHC}$ content in the entire layer. In Regions 1-4 (Area 2), the water volumes of upper layers for each month are substantially lower than their water volumes in lower layers. Therefore, the $\mathrm{BP}_{B 2}$ values for the water volume in upper layers are substantially lower than those for the lower layers of water. The established $\mathrm{BP}_{B 2}$ fluctuations in each month for the entire water volume of the upper layer in the Regions $1-4$ are $0.83-1924.89,23.33-675.02,7.35-749.26$, and 18.20-367.62 thous. $\mathrm{t}$ of $\mathrm{OHC} / \mathrm{month}$, and the highest their values in Regions 1-3 fall in October, and in the Region 4 - in September. The total for the year $\mathrm{BP}_{B 2}$ for the upper layer in Regions 1 and 3 (respectively 6155.88 and 2991.47 thous. $t$ of OHC) is higher than the $\mathrm{BP}_{B 2}$ values for Regions 2 and 4 (respectively, 1970.64 and 1343.41 thous. $t$ of $\mathrm{OHC}$ ) (Table 2). 
Table 2. Calculated production values for OHC-oxidizing $B 2$ bacteria in various months and for a year for Regions $1-4$ (Area 2) (dash means - not calculated for a year; ${ }^{*}$ - dimension is thousand $\mathrm{t}$ of $\mathrm{OHC} / \mathrm{year}$

\begin{tabular}{|c|c|c|c|c|c|}
\hline \multirow{2}{*}{ Month } & \multicolumn{2}{|c|}{ Upper layer } & \multicolumn{2}{|c|}{ Lower layer } & \multirow{2}{*}{$\begin{array}{c}\text { Total for two layers } \\
10^{3} \mathrm{t} \mathrm{OHC} \\
\text { month }\end{array}$} \\
\hline & $\begin{array}{c}\mathrm{g} \mathrm{OHC} \\
\mathrm{m}^{3} \times \text { month }\end{array}$ & $\begin{array}{c}10^{3} \text { t OHC } \\
\text { month }\end{array}$ & $\begin{array}{c}\mathrm{g} \mathrm{OHC} \\
\mathrm{m}^{3} \times \text { month }\end{array}$ & $\begin{array}{c}10^{3} \text { t OHC } \\
\text { month }\end{array}$ & \\
\hline \multicolumn{6}{|c|}{ Region 1} \\
\hline $\begin{array}{l}\text { January } \\
\text { February } \\
\text { March } \\
\text { April } \\
\text { May } \\
\text { June } \\
\text { July } \\
\text { August } \\
\text { September } \\
\text { October } \\
\text { November } \\
\text { December } \\
\text { For a year } \\
\end{array}$ & $\begin{array}{c}-0.0013 \\
-0.0001 \\
-0.0001 \\
-0.0002 \\
-0.0009 \\
0.0009 \\
0.3061 \\
0.7225 \\
0.7271 \\
0.6688 \\
0.1967 \\
-0.0061 \\
- \\
\end{array}$ & $\begin{array}{c}-9.64 \\
-0.83 \\
-0.96 \\
-1.35 \\
-6.24 \\
0.83 \\
440.46 \\
1386.22 \\
1743.90 \\
1924.89 \\
707.66 \\
-29.07 \\
6155.88 * \\
\end{array}$ & $\begin{array}{c}0.2795 \\
0.1014 \\
0.0870 \\
0.1022 \\
0.2235 \\
0.4314 \\
0.4855 \\
0.4819 \\
0.4261 \\
0.3926 \\
0.4000 \\
0.4527 \\
- \\
\end{array}$ & $\begin{array}{c}6568.86 \\
2984.04 \\
2044.86 \\
2402.89 \\
5252.13 \\
12830.11 \\
14207.06 \\
13870.49 \\
12058.45 \\
10923.98 \\
10840.12 \\
11727.12 \\
105710.11 * \\
\end{array}$ & $\begin{array}{c}6559.22 \\
2983.21 \\
2043.90 \\
2401.54 \\
5245.89 \\
12830.94 \\
14647.52 \\
15256.71 \\
13802.35 \\
12848.87 \\
11547.78 \\
11698.05 \\
111265.99 * \\
\end{array}$ \\
\hline \multicolumn{6}{|c|}{ Region 2} \\
\hline $\begin{array}{l}\text { January } \\
\text { February } \\
\text { March } \\
\text { April } \\
\text { May } \\
\text { June } \\
\text { July } \\
\text { August } \\
\text { September } \\
\text { October } \\
\text { November } \\
\text { December } \\
\text { For a year } \\
\end{array}$ & $\begin{array}{c}-0.0141 \\
-0.0068 \\
-0.0047 \\
-0.0050 \\
-0.0069 \\
0.0778 \\
0.4219 \\
0.5914 \\
0.7082 \\
0.7500 \\
0.2708 \\
-0.0156 \\
- \\
\end{array}$ & $\begin{array}{c}-31.70 \\
-15.35 \\
-10.62 \\
-11.23 \\
-15.51 \\
23.33 \\
189.84 \\
354.85 \\
531.16 \\
675.02 \\
304.61 \\
-23.33 \\
1971.07 * \\
\end{array}$ & $\begin{array}{c}0.2568 \\
0.0991 \\
0.0784 \\
0.0902 \\
0.2019 \\
0.3697 \\
0.4127 \\
0.4182 \\
0.3637 \\
0.3254 \\
0.3158 \\
0.3442 \\
- \\
\end{array}$ & $\begin{array}{c}5277.44 \\
2035.48 \\
1611.74 \\
1854.43 \\
4149.66 \\
8317.13 \\
9222.82 \\
9283.60 \\
8018.70 \\
7126.04 \\
6844.25 \\
7330.82 \\
71072.11 * \\
\end{array}$ & $\begin{array}{c}5245.74 \\
2020.13 \\
1601.12 \\
1843.20 \\
4134.15 \\
8340.46 \\
9412.66 \\
9638.45 \\
8549.86 \\
7801.06 \\
7148.86 \\
7307.49 \\
73043.18 * \\
\end{array}$ \\
\hline \multicolumn{6}{|c|}{ Region 3} \\
\hline $\begin{array}{l}\text { January } \\
\text { February } \\
\text { March } \\
\text { April } \\
\text { May } \\
\text { June } \\
\text { July } \\
\text { August } \\
\text { September } \\
\text { October } \\
\text { November } \\
\text { December } \\
\text { For a year } \\
\end{array}$ & $\begin{array}{c}-0.0003 \\
-0.0001 \\
-0.0001 \\
-0.0000 \\
-0.0001 \\
0.0239 \\
0.4335 \\
0.4182 \\
0.3395 \\
0.3568 \\
0.2232 \\
0.0021 \\
- \\
\end{array}$ & $\begin{array}{c}-1.63 \\
-0.26 \\
-0.21 \\
-0.18 \\
-0.20 \\
16.70 \\
455.12 \\
585.54 \\
594.16 \\
749.26 \\
585.82 \\
7.35 \\
2991.47 \\
\end{array}$ & $\begin{array}{c}0.1334 \\
0.0302 \\
0.0308 \\
0.0310 \\
0.0660 \\
0.1401 \\
0.1787 \\
0.1740 \\
0.1221 \\
0.1248 \\
0.1655 \\
0.1758 \\
- \\
\end{array}$ & $\begin{array}{c}700.30 \\
158.39 \\
161.49 \\
162.70 \\
346.40 \\
1372.98 \\
1688.43 \\
1583.04 \\
1068.11 \\
1048.66 \\
1303.39 \\
1230.39 \\
10824.28 \\
\end{array}$ & $\begin{array}{c}698.67 \\
158.13 \\
161.28 \\
162.52 \\
346.20 \\
1389.68 \\
2143.55 \\
2168.58 \\
1662.27 \\
1797.92 \\
1889.21 \\
1237.74 \\
13815.75 \\
\end{array}$ \\
\hline \multicolumn{6}{|c|}{ Region 4} \\
\hline $\begin{array}{l}\text { January } \\
\text { February } \\
\text { March } \\
\text { April } \\
\text { May } \\
\text { June } \\
\text { July } \\
\text { August } \\
\text { September } \\
\text { October } \\
\text { November } \\
\text { December } \\
\text { For a year } \\
\end{array}$ & $\begin{array}{c}-0.0031 \\
-0.0003 \\
-0.0003 \\
-0.0003 \\
-0.0004 \\
0.0485 \\
0.3353 \\
0.4283 \\
0.3918 \\
0.2844 \\
0.1122 \\
-0.0101 \\
- \\
\end{array}$ & $\begin{array}{c}-8.78 \\
-0.82 \\
-0.55 \\
-0.76 \\
-1.00 \\
18.20 \\
188.77 \\
321.52 \\
367.62 \\
320.24 \\
157.92 \\
-18.90 \\
1343.46^{*} \\
\end{array}$ & $\begin{array}{c}0.1427 \\
0.0264 \\
0.0344 \\
0.0435 \\
0.0678 \\
0.1198 \\
0.1306 \\
0.1305 \\
0.1399 \\
0.2244 \\
0.2673 \\
0.2577 \\
- \\
\end{array}$ & $\begin{array}{c}1533.17 \\
287.36 \\
374.01 \\
473.49 \\
738.33 \\
1596.83 \\
1715.82 \\
1689.50 \\
1784.72 \\
2821.85 \\
3285.16 \\
3046.51 \\
19346.75 * \\
\end{array}$ & $\begin{array}{c}1524.39 \\
286.54 \\
373.46 \\
472.73 \\
737.33 \\
1615.03 \\
1904.59 \\
2011.02 \\
2152.34 \\
3142.09 \\
3443.08 \\
3027.61 \\
20690.21 * \\
\end{array}$ \\
\hline
\end{tabular}


It is also important that in Regions 1-4 (Area 2) in comparison with the upper layer, the conditions for the development of $B 2$ bacteria are generally more favorable in the lower layer (by $T_{\mathrm{w}}$ values and the constant inputs of $\mathrm{OHC}$ from bottom sediments into the water). It means that the values of $B 2$ biomass and $\mathrm{BP}_{B 2}$ are higher in the lower water layer than in upper water layer in these regions.

In Regions 1-4 (Area 2), changes of $\mathrm{BP}_{B 2}$ values calculated on the water volumes of the lower layer in individual months are respectively $0.087-0.486,0.078-0.418$, $0.030-0.179$, and $0.026-0.267 \mathrm{~g} \mathrm{OHC} /\left(\mathrm{m}^{3} \times\right.$ month). High values of $\mathrm{BP}_{B 2}$ in the lower layer coincide with the period of the highest concentrations of $\mathrm{OHC}, B 2$ biomass and the optimal values of their activity indices: in Regions 1-2 - in July-August, (respectively, $0.486-0.482$ and $0.413-0.418 \mathrm{~g} \mathrm{OHC} /\left(\mathrm{m}^{3} \times\right.$ month $)$, and in the Region $3-$ in July-August and December - (0.179-0.174), and in the Region 4 - in November-December $(0.267-$ $0.258 \mathrm{~g} \mathrm{OHC} /\left(\mathrm{m}^{3} \times\right.$ month $)$ (Table 2$)$.

In lower water layers of Regions 1-4 (Area 2), the ranges of $\mathrm{BP}_{B 2}$ values calculated on the water volumes of these layers are respectively 2044.86-14207.06, 1611.749283.60, 158.39-1688.43, and 287.36-1784.72 thous. $t$ of $\mathrm{OHC} /$ month. The smallest $\mathrm{BP}_{B 2}$ values in all regions fall in February-April (at the least of OHC concentrations and $B 2$ biomasses in waters of this layer). The largest ones are in July (in Regions 1 and 3), August (the Region 2) and September (the Region 4). The annual $\mathrm{BP}_{B 2}$ values in lower layers in these regions are respectively 105710.11, 71072.11, 10824.29 and 19346.75 thous. $t$ of OHC (Table 2).

The annual $\mathrm{BP}_{B 2}$ values for the entire water column for Regions 1-4 are 111265.99, $73943.18,13815.75$ and 20690.21 thous. $t$ of OHC respectively (Table 2). They depend on the volume of water masses in the regions: the largest $\mathrm{BP}_{B 2}$ was obtained for Region 1 (water volume $V=30,700 \mathrm{~km}^{3}$ ), and further for Regions 2, 4, and $3(22800,13700,10500$ $\mathrm{km}^{3}$, respectively).

\section{Conclusions}

In these biohydrochemical studies of marine waters in Sakhalin Eastern Shelf, three electronic instruments were used for the analysis of oceanographic information: 1. GIS "Sakhalin Shelf" (for processing and systematization of thermohaline parameters of marine waters); 2 . The oceanic model of the Bergen University (to calculate the current variables - their rates, directions, and also flow rates of water exchange values between the certain regions within the Eastern Shelf); and 3. CNPSi-model (to calculate the biotransformation of oil hydrocarbons taking into account the intra-annual changes of the marine environment parameters).

The input data for playing the CNPSi-model includes the long-term values of monthly mean of external factors (temperature, light intensity, transparency of the water, nutrient loading, water exchange parameters) that reproduce the development of the transitional states of the studied ecosystem, traced by the intra-annual change in the concentrations of chemicals substances and organism biomasses. The CNPS-model allows studying the reaction of the aquatic ecosystem to the changing external and internal 
factors determining the state of the marine environment and, particularly, the conditions of $\mathrm{OHC}$ transformation as a result of $B 2$ biomass activity and intensity of water exchange between marine regions within the Eastern Shelf of Sakhalin Island.

The analysis of oceanological observations allows us to make two separate water areas -1 . southeastern (with Regions 1-3) and 2. notheastern (with Regions 1-4) within the Eastern Shelf of Sakhalin Island. Set of morphometric data (mean depth, square and water volumes) and oceanological state parameters required for the runing of CNPSimodel were estimated on the base of the GIS «Sakhalin Shelf» and from some literature sources. Water regime, current and flow rate water exchange parameters for regions within Areas 1 and 2 were estimated on the base oceanological data and calculations with the help of ocean dynamic model developed in the Bergen University.

Differences in the values morphometric figures, of marine environment parameters, intensity of water exchanges (vertical between upper and lower layers and horizontal between the regions and with the open waters of the Sea of Okhotsk) determine a certain impacts on the biohydrochemical transformation processes in the water environment, and also on the growth and activity of organism biomass including OHC-oxidizing $B 2$ bacteria in water Areas 1 and 2. One of the aim of this study was to explain the reason of the low biomass production (and particularly for B2 bacteria) in Regions 1-3 (Area 1) where there are more favorable the condition for the development of biomass of organisms than in Regions 1-4 (Area 2).

In Regions 1-3 (Area 1), the intra-annual calculated OHC concentrations vary in different ways: from the beginning of a year with small fluctuations, and then with acceleration (Region 1), with gradual increase in concentrations with different rates (Regions 2 and 3); and the winter OHC accumulation in waters of Regions 1-3 is replaced by their rapid decrease to the minimum values respectively to 159 th, 173rd and 152nd days (down to 2, 0.2 and $0.8 \mu \mathrm{g} \mathrm{OHC} / \mathrm{L}$ ). The period of minimal $\mathrm{OHC}$ concentrations is preserved in Regions 1-3 until 308-329th days.

The dynamics of $\mathrm{OHC}$ concentrations determines the seasonal changes in the conditions for the development of the bacteria $B 2$ and growth its biomass. In Region 1, two maxima of $B 2$ biomass form: a sharp peak at $152^{\text {nd }}$ days $(0.0095 \mathrm{mg} \mathrm{OHC} / \mathrm{L}$ at the highest values of $k_{O B 2}\left(0.238\right.$ day $^{-1}$ on the 137 th day $)$ and a sufficiently long period of its increased values by 236-281st day (with biomass fluctuations in the range 0.0097$0.0106 \mathrm{mg} \mathrm{OHC} / \mathrm{L}$ at the highest values of $k_{0 B 2} 0.011 \mathrm{day}^{-1}$ on the 209th day). In the deepwater Regions 2 and 3, the highest $B 2$ biomass values are reached at the 236th and 180 th days $(0.013$ and $0.014 \mathrm{mg} \mathrm{OHC/L})$ at the largest values of $k_{0 B 2} 0.103$ and 0.130 day $^{-1}$ (accounted for in Regions 2 and 3 respectively at 154th and 135th days).

In the period (156-294th days), the $B 2$ biomass in each region corresponds to the background concentrations of the $\mathrm{OHC}$, and the values of $k_{0 B 2}$ fluctuate near zero values and show on the whole the conditions close to equilibrium for which the $B 2$ biomass fluctuates within its mean values. For Regions $1-3$, the estimated most values of $\mathrm{BP}_{B 2}$ are $0.449,0.194$ and 0.720 thous. $\mathrm{O}$ OHC/L (for Regions 1 and 3 they characterize the conditions in May, and for Region 2 in July). In other months, values of $\mathrm{BP}_{B 2}$ are negative. 
The period of active reduction of $B 2$ biomass occurs in the last ten days of November (from 320ty day), and the significant growth and recovery of concentrations of OHC in the waters of regions occurs after 329th day.

Indicator of $B 2$ biomass activity and their behavior in Regions 1-3 during a year may be $t r_{B 2}$ :values: until the middle of April, in Region 1 the mean $t r_{B 2}$ value is 9.8 days (means a slow turnover of $B 2$ biomass), and at the same period in Regions 2 and $3-t r_{B 2}$ values are $0.5-0.8$ days (this is a result of intensive water exchange between regions and influence on $\mathrm{OHC}$ content and $B 2$ biomass). In period May - middle of November, at the equal conditions of the $B 2$ biomass growth in all regions, the fluctuations of $t r_{B 2}$ were very small and practically uniform (2.0-2.2 days) in all regions.

In upper layer (in Regions 1-4, Area 2), the OHC concentrations until $\sim 125$ th day vary little. The intermediate maximum of OHC is marked on the 180th, 164th, 154th and 168th days (correspondingly $0.0135,0.0142,0.0734$ and $0.0252 \mathrm{mg} \mathrm{OHC} / \mathrm{L}$ ) in these regions. Decrease in $\mathrm{OHC}$ concentrations begins after active growth of $B 2$ biomass (at 185-197th days). Values of $B 2$ biomass turnover before their active growth were faster in the Region 2 ( $t r_{B 2}=0.5-1.8$ days), and in other region these values were slower $\left(t r_{B 2}=\right.$ 1.0-3.0 days). In Regions 1-4, the maximal values of $B 2$ biomass were noted respectively on the 245th, 272nd, 192nd, and 219th days (0.0252, 0.0245, 0.0172 and $0.0145 \mathrm{mg}$ $\mathrm{OHC} / \mathrm{L})$. The highest values of $k_{0 B 2}\left(0.154-0.196 \mathrm{day}^{-1}\right)$ were found at the $171-188$ th days at the active growth of $B 2$ biomass. The $t r_{B 2}$ values in all regions were (2.0-2.2 days) at the highest $B 2$ biomass. The decrease of the $\mathrm{OHC}$ concentrations (down to 0.2-2.7 $\mu \mathrm{g} \mathrm{OHC} / \mathrm{L})$ occurs in the Regions $1-4$ in the period 196-315th days. The values of $B 2$ biomass on 315 th day reduce to (4.6-27.2) $\times 10^{-2} \mu \mathrm{g} \mathrm{OHC} / \mathrm{L}$, and $t r_{B 2}$ values reach almost initial numbers (0.6-1.6 days) by the end of a year.

In the lower layer (Area 2), the OHC concentrations increase from $\sim 120$ days. In Regions 1-2, 3 and 4, their highest values (0.0332-0.0338, 0.0104 and $0.0055 \mathrm{mg}$ $\mathrm{OHC} / \mathrm{L})$ were found at the 164-166th days. They persist in Regions 1-3 to 243 days, and then decrease to a minimum (293-294th days), but by the end of a year they increase respectively to $0.0188,0.0181$, and $0.0144 \mathrm{mg} \mathrm{OHC} / \mathrm{L}$. In Region 4, the OHC content increases from 274 th days to a maximum $(0.0273 \mathrm{mg} \mathrm{OHC} / \mathrm{L}$ on 296th-day), and then it decreases by the end of a year (to $0.0177 \mathrm{mg} \mathrm{OHC/L}$ ).

In Regions 1-4, the maximal $B 2$ biomass is formed in lower layer at the values of $k_{0 B 2}\left(0.035-0.038,0.032-0.045,0.032-0.040\right.$, and $0.025-0.032$ days $\left.^{-1}\right)$ registered on 123-161st days. At the largest $B 2$ biomasses, the ranges of $k_{0 B 2}$ decreased to $0.001-0.01$ day $^{-1}$. The values of $t r_{B 2}$ reflect stable conditions for the development of $B 2$ biomass for most part of a year: in Regions 1-4 after first $\sim 45$ days their values varied within a narrow range (2.0-2.3 days).

In Regions 1-4 (Area 2), the values of $\mathrm{BP}_{B 2}$, calculated per unit of water volume water, in the upper layers are positive in periods June-November (Regions 1-2 and 4) and in June-December (Region 3), and in the lower layer - they are positive throughout the whole year. In the upper layer, the highest $\mathrm{BP}_{B 2}$ values in Regions 1-4 are in September, October, July, and August respectively (0.7271, 0.7500, 0.4335 and $0.4283 \mathrm{~g} \mathrm{OHC/}$ 
$\left(\mathrm{m}^{3} \times\right.$ month). In the lower layer, the highest values of $\mathrm{BP}_{B 2}$ in these regions are in July, August, July, and November $\left(0.4855,0.4182,0.1787\right.$ and $0.2673 \mathrm{~g} \mathrm{OHC} /\left(\mathrm{m}^{3} \times\right.$ month $)$.

With the dimension of the $\mathrm{BP}_{B 2}$ for the entire volume of water, their values directly depend on the water volume of each layer and on the total $\mathrm{OHC}$ content in the entire layer. In Regions 1-4 (Area 2), the water volumes of upper layers for each month are substantially lower than their water volumes in lower layers. Therefore, the $\mathrm{BP}_{B 2}$ values for the water volume in upper layers are substantially lower than those for the lower layers of water. The established $\mathrm{BP}_{B 2}$ fluctuations in each month for the entire water volume of the upper layer in the Regions 1-4 are 0.83-1924.89, 23.33-675.02, 7.35-749.26, and 18.20-367.62 thous. $\mathrm{t}$ of $\mathrm{OHC} / \mathrm{month}$, and the highest their values in Regions 1-3 fall in October, and in the Region 4 - in September. The total for the year $\mathrm{BP}_{B 2}$ for the upper layer in Regions 1 and 3 (respectively 6155.88 and 2991.47 thous. $t$ of $\mathrm{OHC}$ ) is higher than the $\mathrm{BP}_{B 2}$ values for Regions 2 and 4 (respectively, 1970.64 and 1343.41 thous. $t$ of OHC) (Table 2).

Comparison of the values of $\mathrm{OHC}$ concentrations, $B 2$ biomass and parameters of $B 2$ biomass activity in waters of Areas 1 and 2 gave the following results: in the upper layer, the $\mathrm{OHC}$ concentrations in the first half of a year are generally higher in Regions 1-3 (Area 1) in comparison with Regions 1-2 and 4 (Area 2), and conditionally they can be considered comparable with OHC contents in Region 3 (Area 2). The highest values of $B 2$ biomass (0.010-0.014 $\mathrm{mg} \mathrm{OHC/L}$ ) in the waters of Regions 1-3 (Area 1) are generally lower than the maximums of $B 2$ biomass $(0.014-0.026 \mathrm{mg} \mathrm{OHC} / \mathrm{L})$ that form later in Regions 1-4 (Area 2 ). In Regions 1-3 (Area 1), the maximum of $B 2$ biomass is formed at the values of $k_{0 B 2}\left(0.103-0.236\right.$ day $\left.^{-1}\right)$, and in Regions $1-4$ (Area 2) $-k_{0 B 2}$ values are $0.154-0.196$ day $^{-1}$. At the highest values of $B 2$ biomass, the time of full turnover of $B 2$ biomass $\left(\operatorname{tr}_{B 2}\right)$ was the same in all regions of the eastern shelf of Sakhalin and varied in a range of 2.0-2.2 days.

The values of biomass of organisms and parameters of biomass activity $\left(k_{0 B 2}\right.$ and $t r_{B 2}$ ) are objective characteristics of the marine environment state and the biochemical transformation of substances in these conditions. The most important indicator of biomass activity is the value of its production $\mathrm{BP}_{\mathrm{i}}$ calculated by the internal fluxes of substances spent on building biomass. The final values of $\mathrm{BP}_{\mathrm{i}}$ differ in regions as a result of differences in values of their morphometric parameters, indicators of the state of the aquatic environment and water exchange. In Area 1 during the most part of a year, there is an increased transfer of substances and $B 2$ biomass through the boundaries of the regions. This is the main reason for the creation of the negative BPi values in regions of Area 1 for most part of a year. As a rule, the highest values of BPi are formed during the system reorganization of the water transfer (occurs twice in a year - in May-June and September-October). It is during these periods that the velocities of currents and water exchange significantly decrease. This explains why in these months the positive values of $\mathrm{BP}_{B 2}$ in the waters of Area 1 were noted (in the remaining months, B2 biomass participates in continuous bilateral transfer across the boundaries of regions and formally 
falls into the category of introduced biomass (for the considered region it is not taken into account, because it is assumed that this biomass was created in the neighboring regions).

An analysis of environmental data and construction of input data files for calculations on a simulation model was carried out with the financial support of the Russian Foundation for Basic Research (Grant No. 17-05-00365). As a whole, this study was conducted in Shirshov Institute of Oceanology (Russian Academy of Sciences) in the frame of the State Task on the Topic № 0149-2018-0015 and in the State Sakhalin University - on the Topic № 5.9510.2017/8.9.

\section{References}

Fashchuk D.Ja., Ovsienko S.N., Leonov A.V. et al. Geoekologicheskie posledstviay avarijnyh razlivov nefti (Geoecological consequenses of accident oil spilles). Izv. RAS. Ser. Geographich., 2003, No. 5, pp. 57-73.

Lebedeva E.S. Zagriaznenie shellfa morej Rossii nefyianymi urlevodorodami i pesticidami (Pollution of the Russia Sea Shelf by Oil Hydrocarbons and Pesticides) "Geoecology of shelf and coasts of Russian seas". Moscow: Noosphera, 2001, pp. 289-327, [In Russian].

Leonov A.V. Modelirovanie prirodnykh protsessov na osnove imitatsionnoi gidroekologicheskoi modeli transformatsii soedinenii S, N, P, Si: uchebnoe posobie (Modeling of natural processes based on the simulation hydrogeoecological model of transformations of $\mathrm{S}, \mathrm{N}, \mathrm{P}$, and Si compounds: an educational aid), Yuzhno-Sakhalinsk: SakhGU, 2012, [In Russian].

Leonov A.V., Pishchal'nik V.M., and Zaripov O.M., Modelirovanie prirodnykh protsessov: sistema otobrazheniya rezul'tatov raschetov na CNPSi-modeli: uchebnoe posobie (Simulation of Natural Processes: System for Displaying the Results of CNPSi-Model Calculation: An Educational Aid), Yuzhno-Sakhalinsk: SakhGU, 2012, [In Russian].

Leonov A.V., Semenyak L.V., and Chicherina O.V. Hydrocarbons in the White Sea: their inflow and transformation in marine environment in different regions). Water Resources, 2017, Vol. 44, No. 1, pp. 78-100.

Luchin V.A. Water circulation in the Sea of Okhotsk and its annual variations by the results of diagnostic calculations. Tr. DVNII, 1987, No. 36, pp. 3-13, [In Russian].

Luchin V.A. Seasonal variations of water temperature in the active layer of Far East Seas, in Dal'nevostochnye moray Rossii. Kn. 1. Okeanologicheskie issledovaniya (Russian Far East Seas: Book 1. Oceanological Studies), Moscow: Nauka, 2007, pp. 232-252, [In Russian].

Luchin V.A. and Zhigalov I.A. Mezhgodovye izmeneniya tipovyh raspredelenii temperatury vody $\mathrm{v}$ deiatel'nom sloe Ohotskogo moria I vozmozhnost' ih prognoza. Izv. Tikhookeanskogo Nauchno-Issled. Inst. Rybn. Khoz. i Okeanogr., 2006, Vol. 147, pp. 183-204, [In Russian].

Luchin V.A., Lavrent'ev. V.M., and Yarichin V.G. Hydrological regime. In project "Moria". Gidrometeorologiyai gydrochimiya morei. T.IX. Vyp. 1.("Seas"Project. Hydrometeorology of Seas, Vol. IX, No. 1), St. Petersburg: Gydrometeoizdat, 1998, pp. 92-175, [In Russian].

Luchin V.A., Motorykina T.S., Yarichin V.G., and Matveev V.I. Hydrochemical conditions, in Proekt "Morya". Gidrometeorologiya i gidrokhimiya morei (Project "Seas." Hydrometeorology and Hydrochemistry of Seas), Vol. IX, No. 2, St. Petersburg: Gidrometeoizdat, 1993, pp. 6-80. [In Russian].

Mogilnikova T.A., Motylkova I.V., and Konovalova N.V. The phytoplankton of a northeast shelf of Sakhalin in September 2001. Proc. of the 18th Intern. Symp. on Okhotsk sea \& Sea ice. The Okhotsk sea \& Cold Ocean Research Association. Japan, Hokkaido, Mombetsu, 2003, 308 p. 
Nemirovskaya I.A. Neft' v okeane. Zagriaznenie i prirodnye potoku (Oil in the Ocean. Pollution and Natural Flows). Moscow: Nauchnyj Mir, 2013a, [In Russian].

Nemirovskaya I.A. Osobennost' raspredelemiya i sostava urlevodorodov v donnyh osadkah Shtokmanovskogo mestorozhdenija, Barents Sea (Feature of Distribution and Hydrocarbon Composition in Sediments of Shtokman Deposit (Barents Sea). Doclady Russian Academy of Sci., 2013 b, Vol. 452, No. 2, pp. 196-201, [In Russian].

Patin S.A. Nefnianye razlivy i ih vozdejstvie na morskuju sredy i bioresursy (Oil Spill and it Influence on Marime Environment and Bioresources). Moscow: VNIRO, 2008, [In Russian].

Pishchal'nik V.M., Arkhipkin V.S., and Leonov A.V. Reconstruction of the annual variations of thermohaline characteristics and water circulation on the northeastern Sakhalin Shelf. Water Resour., 2014, Vol. 41, No. 4, pp. 385-396.

Pishchal'nik V.M., Arkhipkin V.S., and Leonov A.V. Modelirovanie srednemesiachnuh termohalinnyh karakteristi I cirkuliacii vod na ugo-vostochnom shelfe Sahalina (Modeling mean month thermohaline patterns and water circulation on southeastern shelf of Sakhalin). Izvestiya TINRO, 2017, Vol. 191, pp. 160-175, [In Russian].

Pishchal'nik V.M. and Bobkov A.O. Okeanograficheskii atlas shel'fovoi zony ostrova Sakhalin (Oceanographic atlas of the shelf zone of Sakhalin Island), Yuzhno-Sakhalinsk: SakhGU, 2000, [In Russian].

Polteva A.V., Latkovskaya E.M., and Leonov A.V. Assessment of the background ecological state of water in the Chayvo Bay, Northeastern Sakhalin. Water Resour., 2009, Vol. 36, No. 1, pp. 86-99.

Zakharkov S.P., Selina M.S., Vanin N.S., et al. Phytoplankton characteristics and hydrological conditions in the western part of the Sea of Okhotsk in the spring of 1999 and 2000 based on expeditionary and satellite data. Okeanologiya, 2007, Vol. 47, No. 4, pp. 519-530.

\title{
НЕФТЯНЫЕ УГЛЕВОДОРОДЫ В ШЕЛЬФОВЫХ ВОДАХ ВОСТОЧНОЙ ЧАСТИ ОСТРОВА САХАЛИН: ИХ ПОСТУПЛЕНИЕ, ТРАНСФОРМАЦИЯ И СОДЕРЖАНИЕ
}

\author{
Леонов А.В. ${ }^{1}$, Пищальник В.М.' ${ }^{2}$ Петухов В.И. ${ }^{3}$, Чичерина О.В. ${ }^{1}$ \\ ${ }^{1}$ Институт океанологии им. П.П. Ширшова РАН, 117997, Москва, \\ Нахимовский проспект, д.36, е-mail:leonov@осеап.ru \\ ${ }^{2}$ Сахалинский Государственный университет, Южно-Сахалинск, ул. Ленина, 290 \\ ${ }^{3}$ Дальневосточный федеральный университет, Владивосток, ул. Суханова, 8 \\ Статья поступила в редакцию 16.02.2019, одобрена к печати 29.04.2019
}

На основе методологии математического моделирования исследовано развитие трансформации нефтяных углеводородов в водах восточного шельфа о-ва Сахалин. Для анализа океанографической информации использовались три электронных инструмента: 1. ГИС «Сахалинский шельф» (для обработки и систематизации термохалинных наблюдаемых параметров); 2. Океаническая модель Бергенского университета (для расчета скоростей и направлений течений, а также скоростей водообмена между отдельными районами на шельфе о-ва Сахалин); 3. Модель CNPSi (для расчета биотрансформации нефтяных углеводородов с учетом внутригодовых долгосрочных изменений параметров морской среды и особенностей переноса вещества при водообмене). Весь восточный шельф о-ва Сахалин был подразделен 
на две акватории (1. юго-восточная и 2. северо-восточная), в пределах которых были выделены районы 1-3 и 1-4 соответственно. С помощью расчетов на математической CNPSi-модели воспроизведено взаимодействие меняющихся факторов окружающей среды в течение года (температура, интенсивность света, прозрачность воды, поступления углеводородов нефти из внешних источников, условия водного режима) и их влияние на биотрансформацию нефтяных углеводородов в двухслойной морской системе в восточной части шельфа Сахалина. Модель рассчитывает изменения в течение года концентраций нефтяных углеводородов, биомассы бактерий $B 2$ (они окисляются нефтяные углеводороды) и показателей их активности (удельная скорость роста, общее время оборота и продукция биомассы). Проанализированы изменения этих параметров в зависимости от факторов окружающей среды и условий переноса вещества при водообмене через границы регионов и с акваториями Охотского моря. Для каждого исследуемого региона выявлены характерные значения этих параметров для конкретных периодов года. Расчеты показывают, что существуют различные условия для формирования биомассы бактерий $B 2$ и их продукции в южных и северных районах восточного шельфа о-ва Сахалин. В районах 1-3 юго-восточной части шельфа (Акватория 1) было обнаружено значительное влияние динамики воды на развитие биомассы организмов и, в частности, на биомассу $B 2$.

Ключевые слова: нефтяные углеводороды, биомасса нефтеокисляющих бактерий в морских водах восточного шельфа острова Сахалин; их поступления, биотрансформация и динамика в течение года; показатели активности нефтеокисляющих бактерий (удельная скорость роста, оборот биомассы, продукция).

\section{Литература}

Захаров С.П., Селина М.С., Ванин Н.С. и др. Характеристика фитопланктона и гидрологических условий в западной части Охотского моря весной 1999 и 2000 гг. на основе экспедиционных и спутниковых данных // Океанология. 2007. T. 47. № 4. С. 519-530.

Лебедева Е.C. Загрязнение шельфа морей России нефтяными углеводородами и пестицидами / В кн.: Геоэкология шельфа и побережья морей России. М.: Ноосфера, 2001. С. 289-329.

Леонов A.B. Моделирование природных процессов на основе имитационной гидроэкологической модели трансформации соединений C, N, P, Si: учебное пособие. Южно-Сахалинск: СахГУ, 2012.

Леонов А.В., Пищальник В.М., Зарипов О.М. Моделирование природных процессов: система отображения результатов расчетов на CNPSi-модели: Учебное пособие. Южно-Сахалинск: СахГУ, 2012.

Леонов А.В., Семеняк Л.В., Чичерина О.В. Углеводороды в Белом море: их поступление и трансформация в морской среде в разных районах // Водные ресурсы. 2017. Т. 44. № 1. С. 38-62.

Лючин B.A. Циркуляция воды в Охотском море и их годовые вариации по результатам диагностических расчетов // Тр. ДВНИИ. 1987. № 36. С. 3-13.

Лючин В.A. Сезонная изменчивость температуры воды в деятельном слое Дальневосточных морей // Дальневосточные моря России. Книга 1 Океанологические исследования. М.: Наука, 2007. С. 232-252.

Лючин В.А., Жигалов И.А. Межгодовые изменения типовых распределений температуры воды в деятельном слое Охотского моря. Проект «Моря» // 
Изв. Тихоокеанского НИИ Рыбного Хозяйства и Океанографии. 2006. Т. 147. C. 183-204.

Лючин В.А., Лаврентьев В.М., Яричин В.Г. Гидрологический режим // Проект «Моря». Гидрометеорология и гидрохимия морей. Т. IX. Охотское море. Вып. 1. Гидрометеорологические условия. СПб.: Гидрометеоиздат, 1998. С. 92-175. Лючин В.А., Моторыкина Т.С., Яричин В.Г., Матвеев В.И. Гидрохимические условия // Проект «Моря». Гидрометеорология и гидрохимия морей / T. IX. Охотское море. Вып. 2. Гидрохимические условия и океанографические основы формирования биологической продуктивности. СПб.: Гидрометеоиздат, 1993. C. 6-80.

Могильникова Т.А., Мотылькова И.В., Коновалова Н.В. Фитопланктон северовосточного шельфа Сахалина в Сентябре 2001 г. // Матер. 18-го Интернац. Симпозиума по Охотскому морю и морскому льду. Япония. Хоккайдо. Момбетсу: 2003. С. 308.

Немировская И.А. Нефть к океане. Загрязнение и природные потоки. М.: Научный мир, 2013 а. 432 с.

Немировская И.А. Особенности распределения и состава углеводородов в донных осадках Штоксанского месторождения, Баренцево море // Доклады Российской академии наук. 2013 б. Т. 452. № 2. С. 196-201.

Патин С.A. Нефтяные разливы и их воздействие на морскую среду и биоресурсы. М.: ВНИРО, 2008.

Пищальник B.М., Архипкин В.С., Леонов А.В. Восстановление годового хода термохалинных характеристик и циркуляции вод на северо-восточном шельфе Сахалина // Водные ресурсы. 2014. Т. 41. № 4. С. 362-374.

Пищальник В.М., Архипкин В.С., Леонов А.В. Моделирование среднемесячных термохалинных характеристик и циркуляции вод на юго-восточном шельфе Сахалина // Известия ТИНРО. 2017. Т. 191. С. 160-175.

Пищальник В.М., Бобков А.О. Океанографический атлас шельфовой зоны острова Сахалин. Южно-Сахалинск: СахГУ, 2000.

Полтева А.М., Латковская Е.М., Леонов А.В. Оценка фонового экологического состояния залива Чайво (северо-восточный Сахалин) // Водные ресурсы. 2009. T. 36. № 1. С. 86-101.

Фашук Д.Я., Овсиенко С.Н., Леонов А.В. и др. Геоэкологческие последствия разливов нефти. Известия Российской Академии Наук. Сер. Географич. 2003. № 5. С. $57-73$. 